\title{
Targeted Therapies: Friends or Foes for Patient's NK Cell-Mediated Tumor Immune-Surveillance?
}

\author{
Laura Damele ${ }^{1,+}\left(\mathbb{D}\right.$, Selene Ottonello ${ }^{1,+}+\mathbb{D}$, Maria Cristina Mingari ${ }^{1,2,3}$, Gabriella Pietra ${ }^{1,2, \mp(1)}$ \\ and Chiara Vitale ${ }^{1,2, \ddagger}, *$ \\ 1 UO Immunologia IRCCS Ospedale Policlinico San Martino, 16132 Genoa, Italy; \\ lauradamele91@gmail.com (L.D.); sele_8@hotmail.it (S.O.); mariacristina.mingari@unige.it (M.C.M.); \\ gabriella.pietra@unige.it (G.P.) \\ 2 Dipartimento Medicina Sperimentale (DIMES), Università degli Studi di Genova, 16132 Genoa, Italy \\ 3 Centre of Excellence for Biomedical Research (CEBR), Università degli Studi di Genova, 16132 Genoa, Italy \\ * Correspondence: chiara.vitale@unige.it \\ $+\quad$ L.D. and S.O. share first co-author authorship. \\ $\ddagger$ G.P. and C.V. share co-senior authorship.
}

Received: 7 February 2020; Accepted: 23 March 2020; Published: 25 March 2020

\begin{abstract}
In the last 20 years there has been a huge increase in the number of novel drugs for cancer treatment. Most of them exploit their ability to target specific oncogenic mutations in the tumors (targeted therapies-TT), while others target the immune-checkpoint inhibitor molecules (ICI) or the epigenetic DNA modifications. Among them, TT are the longest established drugs exploited against a wide spectrum of both solid and hematological tumors, often with reasonable costs and good efficacy as compared to other innovative therapies (i.e., ICI). Although they have greatly improved the treatment of cancer patients and their survival, patients often relapse or develop drug-resistance, leading to the impossibility to eradicate the disease. The outcome of TT has been often correlated with their ability to affect not only tumor cells, but also the repertoire of immune cells and their ability to interact with cancer cells. Thus, the possibility to create novel synergies among drugs an immunotherapy prompted scientists and physicians to deeply characterize the effects of TT on immune cells both by in-vitro and by ex-vivo analyses. In this context, NK cells may represent a key issue, since they have been shown to exert a potent anti-tumor activity, both against hematological malignancies and solid tumors. In the present review we will discuss most recent ex-vivo analyses that clarify the effect of TT treatment on patient's NK cells comparing them with clinical outcome and previous in-vitro data.
\end{abstract}

Keywords: NK cells; targeted immunotherapy; cancer immunosurveillance

\section{Introduction}

Targeted therapies (TT) act by inhibiting and disrupting biochemical pathways that play a key role in tumor cell growth and survival. They have been shown to induce significative tumor regression and improve overall survival of molecularly defined subsets of patients, both in solid and hematological malignancies [1-3].

Imatinib was the first tyrosine kinase inhibitor (TKI) designed to interfere with kinase activity of p190 and p210 oncoproteins, generated by the chimeric gene BCR-ABL, originating from translocation between terminal fragment of chromosome 9 and chromosome 22, that generates the Philadelphia chromosome $\left(\mathrm{Ph}^{+}\right)$, the typical marker of chronic myeloid leukemia (CML) [4]. The dramatic success of this drug opened the door to the identification of novel molecular targets and to the design on novel drugs. In solid tumors the main target of these drugs are oncoproteins crucial for tumor maintenance 
and survival such as epidermal growth factor (EGFR), B-Raf proto-oncogene/serine/threonine kinase (BRAF), proto-oncogene c-Kit (KIT), human epidermal growth factor receptor 2 (HER2) [3,5].

Patients generally respond rapidly to these small-molecule kinase inhibitors however, after striking initial regression, tumors develop drug-resistance variants, leading to the progression of the disease. This phenomenon is particularly relevant for solid tumors, while in hematological tumors another major issue is the life-long treatment that these therapies may require, as their discontinuation may lead to relapse in half of patients $[5,6]$. Thus, these therapies are not curative, may exert several sides effects and raise concerns for the economic burden of treatments [6,7]. Among off-sides effects, these compounds exert an immunomodulatory effect of the immune system due to their ability to target several proteins involved in immune system development and activation such as proto-oncogene stem cell factor receptor (c-Kit), platelet-derived growth factor receptor (PDGF-R) and vascular endothelial growth factor receptor (VEGF-R), proto-oncogene tyrosine-protein kinase Src kinase family and mitogen-activated protein kinases (MAPK) [8,9]. Thus, several studies attempted to clarify the off-sides effects of these compounds and their interactions with immune systems to define mechanisms contributing to the success of the treatment or to its failure.

In the present review we will focus our attention on the effect of TT on human natural killer (NK) cells in vitro and in vivo. NK cells have been proved to play an important role in anti-tumor immune response, particularly in hematological malignancies. On the other hand, in solid tumors, the exploitation of these cytotoxic cells has resulted very difficult to fulfill up to now and several strategies have been proposed [10-14]. Thus, a detailed analysis of the effects of TT therapy may contribute to understand the possibilities to improve NK cell-mediated control of neoplastic disease.

\section{Natural Killer Cells}

NK cells are thought to represent one of the major host effector cells to control tumor development and progression $[11,13,15,16]$. Upon activation, they can exert powerful cytotoxicity against tumor- transformed cells by the release of molecules such as perforin and granzymes, of several chemokines such as MIP-1 $\alpha / \beta$, Chemokine (C-C motif) Ligand 5 (CCL5), Chemokine (C-X-C motif) Ligand 1 (CXCL1), and cytokines, such as Interferon (IFN)- $\gamma$, Tumor Necrosis Factor (TNF)- $\alpha$, Granulocyte-Macrophage Colony-Stimulating Factor (GM-CSF), or Interleukin (IL)-10, which can differently modulate inflammatory responses $[15,17,18]$. NK cells represent $5-15 \%$ of circulating lymphocytes in peripheral blood (PB), and can migrate in peripheral tissues and in secondary lymphoid tissues (SLT) $[19,20]$ (Figure 1). In SLT, they provide an early source of IFN- $\gamma$ and interact with dendritic cells (DCs) playing an important role in DCs maturation and thus in the promotion Thelper cell type 1 (Th1) responses [21-23]. 
A
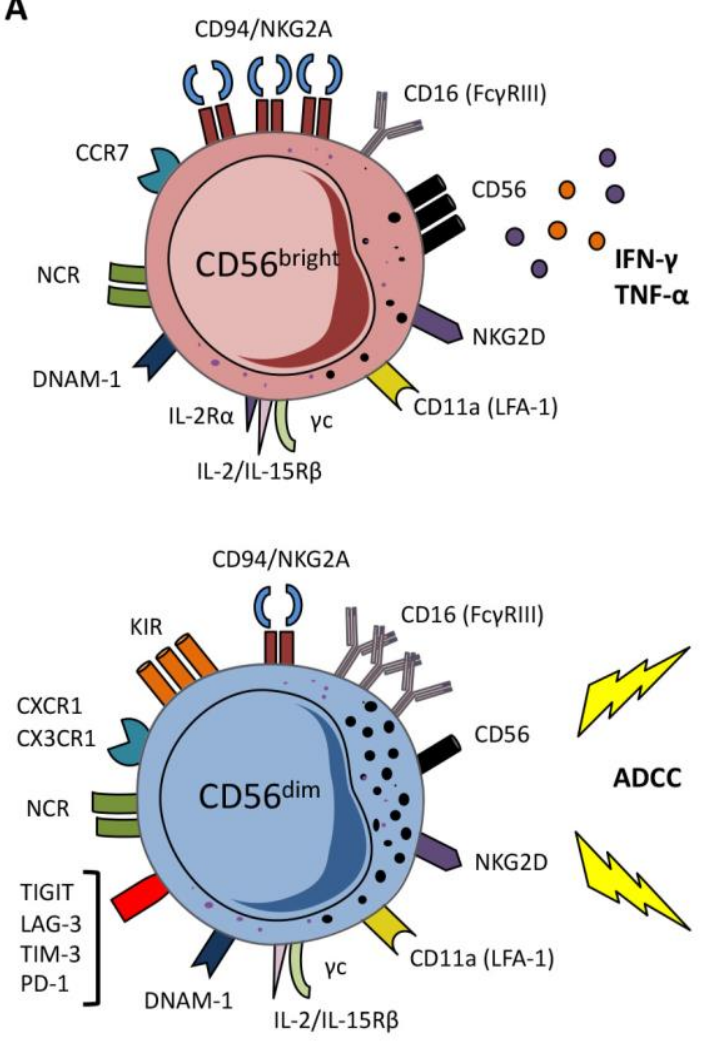

Tumor cell

1

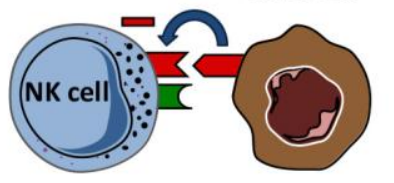

Inhibitory ligand No lysis

2
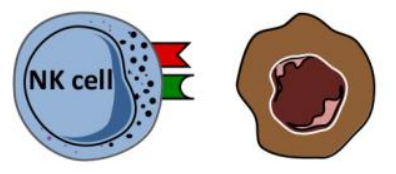

No a/i-ligands No lysis

Tumor cell lysis

3
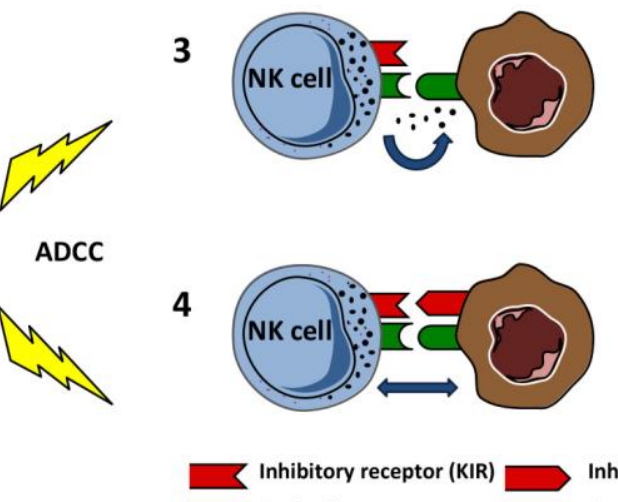
B 
mixed-lineage leukemia-5 (MLL5), sindecan-4, galectin-3 and soluble ligand NID1 (NKp44-L), CFP and other viral ligands (NKp46-L), PVR (CD112) and nectin-2 (CD155) are DNAM-1 ligands, while MIC-A/B and ULBPs are ligands for NKG2D receptor, which is a C- type lectin molecule [31-33]. The 2B4 receptor belongs to the family of signaling lymphocyte activation molecule (SLAM)-related receptors (SRR) and recognizes CD48 molecule. NK-T-B-antigen (NTB-A) protein is similar to 2B4 protein both structurally and functionally, but the activation requires a homophile bond with another NTB-A molecule [34]. Finally, NKp80 receptor, expressed as dimer, recognizes AICL molecule (expressed by activating monocytes and tumor cells) [35]. NK cells can also express other immunomodulatory receptors such as TIGIT (T cell immunoreceptor with Ig and ITIM domain), CD96, TIM-3 T cell immunoglobulin domain and mucindomain-3), PD-1 (programmed death-1) and LAG-3 [36]. TIGIT and CD96 are detectable on resting NK cells and compete with the activating receptor DNAM-1 for the same ligands, in particular for CD155. Thus, crosslinking of CD155 by TIGIT inhibits NK cell cytotoxicity, while CD96 seems to preferentially modulate IFN- $\gamma$ production [37]. TIM-3 is expressed by resting CD56 ${ }^{\mathrm{dim}} \mathrm{CD} 16^{+} \mathrm{NK}$ cells while CD56 ${ }^{\text {bright }}$ NK cells may acquire its expression upon cytokine stimulation. It is considered a marker of NK cell activation/maturation [38]: main ligands are galectin-9, phosphatidyl serine, high mobility group box-1 (HMGB-1) and carcinoembryonic antigen-related cell adhesion molecule-1 (CEACAM-1). TIM-3 inhibitory activity on NK cells is still controversial and seems to depend upon the type of stimulation used [36]. PD-1 is expressed on limited percentages of resting CD56 ${ }^{\mathrm{dim}} \mathrm{CD} 16^{+}$ $\mathrm{KIR}^{+} \mathrm{CD} 57^{+} \mathrm{NK}$ cells.

Similarly to TIM-3, it is considered a marker of NK cell terminal differentiation, identifying memory-like NK cells or functionally exhausted NK cells. Finally, LAG-3 is expressed on activated NK cells but its role on human NK cell functions is still unclear [36]. Generally, most these receptors are upregulated on human NK cells isolated from PB or tissue biopsies from patients affected by different types of tumors, suggesting that their acquisition favors the enrichment in NK cells with low functionality or exhausted features [36].

Receptor interaction with ligand leads to activation of NK cytolytic activity but, in the absence of strong cytokine activation, the engagement of at least two of activating receptors on NK cells is required to trigger degranulation $[39,40]$. On the other hand, the other major activating receptor, the Fc $\gamma$ RIIIA receptor (CD16), can trigger degranulation alone upon binding of an antibody bound to a target cell, the so called antibody-dependent cellular cytotoxicity (ADCC) [40].

In addition, NK cells may express the activating counterparts of HLA-class I specific receptors (i.e., activating KIRs and CD94/NKG2C). The specificity of these latter receptors for HLA-I molecules has been formally defined only for KIRDS1, KIR2DS4 and NKG2C, and their role in addressing NK cytotoxicity has not yet been clearly defined [41-46].

The type and the quantity of receptors involved in NK-target cell interaction dictates the nature (activating vs inhibitory) of the immunological synapse and the consequent decision on granule release. Many tumor cell lines often express the ligands for different activating receptors and show reduced expression of HLA-class I molecules thus representing potential NK-sensitive targets in vivo (Figure 1).

NK cells are commonly clustered in two main subsets that allow them to patrol the body and interact with different immune cell types in different tissues (Figure 1). In particular, NK cell subsets are differently represented in PB and SLT, representing NK cells in sequential stages of differentiation with different functional features [20,47]. "Terminally differentiated" PB CD56 $6^{\text {dim }}$ CD16 $6^{\text {bright }}$ NK cells expressing CD57 and KIR molecules display high cytotoxic potential and may release high amounts of IFN- $\gamma$ upon NCR triggering. They represent the majority of circulating PB NK cells. On the other

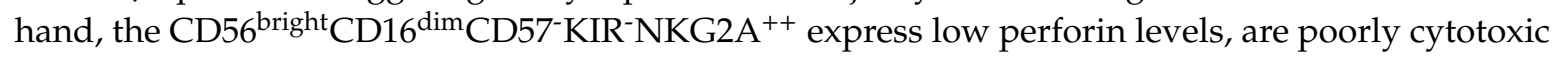
but release large amounts of IFN- $\gamma$ upon cytokine stimulation $[48,49]$. They are mainly distributed in SLT and several tissues. In PB, they can be considered the precursors of CD16 ${ }^{\text {dim }}$ NK cells $[19,20,47]$. 


\section{NK Cells and Hematological Malignancies}

NK cells have been shown to kill in vitro a number of established or primary cell lines derived from several hematologic malignancies, including $\mathrm{T}$ and $\mathrm{B}$ leukemias, myeloid leukemias, lymphomas, and multiple myelomas [30,35,50-53]. Most activating receptors, including the NCRs, NKG2D and DNAM-1 are involved in the recognition and killing of transformed cells [30]. NKG2D and DNAM-1 receptors as well as the NCRs have been reported as important for the targeting of acute and chronic myeloid leukemias (AML,CML) blasts, acute lymphoblastic leukemia (ALL) [30,51,52,54,55], multiple myeloma [53] while the role of DNAM-1 receptor seems to be central in targeting freshly isolated myeloiddysplastic syndrome (MDS) blasts [56]. Importantly, the blockade of inhibitory KIR and CD94/NKG2A increase NK cell mediated killing of leukemic blasts indicating that they express enough HLA-class I to at least partially inhibit NK cells [57]. On the other hand, experimental evidences suggest that the activating counterparts of HLA-class I specific receptors (such as KIR2DS1 ${ }^{+}$), could play a role in in the eradication of AML blasts $[58,59]$.

The importance of the NK cell anti-tumor activity in tumor surveillance is corroborated by many studies showings that NK cells are frequently suppressed/altered in hematologic malignancies.

In CML patients, low numbers of NK cells are associated with defects in their proliferation and weak NK cell cytolytic functions in comparison with healthy donor blood NK cells [60,61]. Similarly, in MDS, the cytolytic activity of NK cells is impaired, even in the presence of IL-2 stimulation in vitro, as compared to NK cells from healthy donors [62]. In these CML/MDS patients, PB NK cells display severe defects including down-regulation of activating receptors, reduced cytotoxic potential, and reduced cytokine-induced proliferation in vitro. Activating NK receptors, such as DNAM-1, NKp30 and NKp46, display a low expression on NK cell surfaces also in AML patients and a parallel increase of expression of CD94/NKG2A inhibitory receptor [63-65]. Along with the phenotypic defects, cytolytic activity and TNF- $\alpha$ and/or IFN- $\gamma$ production are also impaired and associated with poor clinical outcomes [63-66].

Leukemic blasts may directly affect NK cell repertoire and functions. The continuous exposure to the cognate ligands expressed by AML blasts may favor the modulation of corresponding activating receptors on autologous NK cells, leading to an exhaustion of the NK-cell cytotoxicity $[67,68]$. Other markers such as CD96, expressed by a subset of NK cells, or CD200, expressed on AML, may suppress patients NK cell functions $[69,70]$. Similarly, increased proportions of NKp30 low TIM- $3^{+}$NK cells were found in the PB of CLL patients [71] Moreover, leukemic blasts may release various soluble molecules, including soluble ligands of activating NK receptors, soluble factors, such as TGF- $\beta$ or IL-10, reactive oxygen species (ROS), or express high levels of indoeamine-2,3-dioxygenase (IDO) and tryptophan catabolites, which inhibit NK cell functions and modulate NK cell receptors expression [72-76]. In AML patients' serum the presence of soluble NKG2D-L (MICA, MICB and ULBP2) is associated with a down-regulation of the surface NKG2D expression leading to an impairment in NKG2D-mediated NK-cell activity [77]. Soluble ligands can be also detected bound to tumor-derived exosomes in patient's serum. Exosomes from leukemia/lymphoma cells can express NKG2D-L leading to an inhibition of the NK cell activation [78]. On the other hand, while the NKp30 ligand soluble BAG6, released by lymphocytic leukemia cells, works as an inhibitory ligand of NKp30, exosome-bound BAG6 activates NK cells in chronic lymphocytic leukemia (CLL) [79].

Hematological malignancies may favor the expansion of selected NK cell subsets, inducing a perturbation of the NK cell repertoire: AML may induce in some patients a deep NK cell maturation blockade that correlated with poor patient outcomes [80]. A central issue is also whether leukemic cells, in particular leukemic stem cells (LSC) present in the bone marrow, may influence the survival of normal stem cells and their differentiation towards immune cells with potential anti-leukemia activity [81]. Leukemic blasts may contribute to generate aberrant BM niche that competes with normal ones and that favors leukemic stem cell clone survival. ALL blast may rebuild a permissive niche in response to chemotherapy [82] while aberrant BM mesenchymal stromal cells ( $\alpha$-SMA ${ }^{+}$mesenchymal stem cells) and hypoxia may contribute to the reduction of NK cell cytotoxicity against autologous 
AML blasts [83]. AML can also interfere directly with NK cell precursors proliferation and functional maturation. We showed, in a model of in vitro NK cell differentiation, that IL-1 $\beta$-releasing AML blasts could inhibit the recovery of $\mathrm{CD} 34^{+}$-derived $\mathrm{CD} 161^{+} \mathrm{CD} 56^{+}$cells, resulting in a reduced generation of ILC3 and NK cells [84]. Thus, it is possible that IL-1 $\beta$ released by residual AML blasts may alter the BM microenvironment and suppress the proliferation of NK cell precursors [85] Finally, AML blasts may induce the expression of the transcription factor aryl hydrocarbon receptor (AHR) that activates miR-29b in NK cell precursors impairing their maturation and functions [86].

\section{NK Cells and Solid Tumors}

Malignant cells derived from many solid tumors often express the ligand(s) for one or more of the major activating NK receptors including NCRs, DNAM-1, and NKG2D. Beyond their cytotoxic function, NK cells, are found to recruit to tumor sites DCs able to effectively prime T-cell response. In human cancers, intra-tumoral CCL5, XCL1, and XCL2 transcripts closely correlate with NK cells/cDC1 gene signatures and are associated with increased overall patient survival in several cancer types [87]. In addition, these innate cells, through secretion of FlT3-L, control the abundance of intra-tumoral stimulatory DCs and their frequency, that directly correlates with survival of melanoma patients receiving anti-PD-1 therapy [88].

Although many studies have deeply characterized the anti-tumor activity of NK cells both in vitro and in animal models, the exploitation of these cytotoxic cells for the therapy of solid tumors is still far to achieve. These difficulties are essentially related to the few numbers of NK cells present in the tumor bed and the suppressive effects mediated by the local tumor microenvironment on the NK cell effector mechanisms.

Early immunohistochemical studies in tumor biopsies suggested that NK cells might be effective during antitumor responses since their detection correlated with good prognosis of cancer patients [8991]. However, NK cells present in solid tumors (including lung, gastric, colorectal) are usually scarce. Few exceptions are represented by renal cell carcinoma (RCC) and gastrointestinal stromal tumors (GIST), which are infiltrated by a significant number of $\mathrm{NKp} 46^{+}$cells $[92,93]$. Of note, different from hematological malignancies, tumor-infiltrating (TI) NK cells are usually not in direct contact with neoplastic cells, but they are rather located within the stroma.

Besides their relative frequency and numbers, a key limiting factor of tumor-killing capacity of NK cells is their functional impairment. Solid TI-NK cells often display a CD56 $6^{\text {bright }}$ phenotype and/or a reduced expression of the activating receptors resulting in a de-potentiated anti-tumor activity. In breast cancer, NK-TILs are enriched in CD56 $6^{\text {bright }}$ cells expressing NKp44 and CD25 and CD69 activation markers, but exhibit low levels of NKp30, NKG2D, DNAM-1 and CD16 and poor cytotoxic potential [94]. In early-stage NSCLC, NK-TILs are mostly CD56 ${ }^{\text {dim }}$, but express limited amounts of activating receptors (NKp30, NKp80, CD16, and DNAM-1) and display a low degranulation and cytokine release potential [95]. In RCC, infiltrating NK cells express high levels of CD94/NKG2A inhibitory receptor contributing to decreased NK cell activity [92] while in GIST patients, NK cells express predominantly the immunosuppressive NKp30c isoform and display a CD56 ${ }^{\text {bright }}$ CD16-KIRphenotype $[93,96]$. As mentioned above, tumor infiltrating NK cells and circulating NK cells may upregulate several inhibitory checkpoint receptors. TIGIT was found to be associated with NK cells with exhausted phenotype in colon cancer patients [97]. TIM-3 is upregulated on NK cells in several types of cancer while increased proportions of $\mathrm{CD} 56^{+} \mathrm{CD} 96^{+} \mathrm{NK}$ cells can be found in the intra-tumor tissues of HCC: their expression level is associated with poor clinical outcomes or advanced stage of diseases [98-102]. Several studies in humans have shown that NK cells from cancer patients express PD-1 like ovarian cancer and Kaposi sarcoma [103,104]. Of note, blockade of TIM-3, PD-1, TIGIT may restore NK cell cytotoxicity or IFN- $\gamma$ production, suggesting that the therapy with immune-checkpoint inhibitors (ICI) may contribute to restore also NK cell function $[36,105]$.

In order to gain further insight about the functional states of human NK cells in solid tumors, a recent study analyzed the transcriptome of TI-NK cells isolated from human melanoma metastases 
compared with circulating NK cells [106]. Single-cell RNA-seq analysis of TI-NK cells identified different NK cell populations with specialized gene expression programs. Some NK cell subsets are found to expressed high levels of XCL1 and XCL2 chemokines genes that are critical for cross-presenting XCR1+ DCs recruitment into tumors [87], whereas other subsets show a higher perforin and granzyme $\mathrm{B}$ expression. This analysis also reveals that TI-NK cells express higher levels of the KLRC1 gene encoding NKG2A inhibitory receptor than circulating NK cells.

Other tumor-residing cells or tumor cells themselves can hamper NK cell function at the tumor site by mechanisms commonly exploited also by hematological tumors. Thus, tumor associated macrophages (TAM) and other immature myeloid cells (myeloid derived suppressor cells, MDSC) can polarize a Th2 response and/or produce suppressive factors such as IL-10, TGF- $\beta$, ROS or deplete intracellular L-arginine [107]. T-reg represent another cell subset those accumulation in tumors correlates with impaired immune function and poor prognosis. A T-reg increase and a low NK cell activity has been described in gastrointestinal stromal tumor (GIST) and hepatocarcinoma (HCC) tumor-bearing subjects [108]. Tumor-associated fibroblasts, (TAF) are considered to play a pivotal role in mediating suppressive activity toward NK cells. TAF derived from different solid tumors were shown to inhibit NK cell function through both cell-to-cell contact and release of PGE2, which abrogate the IL-2-induced up-regulation of NKp44, DNAM-1 and NKp30 [109-111].

Tumor cells can hamper NK immune response by inhibitory mechanisms such as indoleamine 2,3-dioxygenase (IDO) expression and/or PGE2 production in metastatic melanoma, modulating expression of NKp30, NKp44 and NKG2D [112]. Other soluble tumor-derived factors such as TGF- $\beta$, Macrophage migration inhibitory factor (MIF), MUC-16 and adenosine [113] can impair NK cells. In neuroblastoma, TGF- $\beta$ inhibits NK cell functions by modulating activating receptor expression and chemokine-receptor repertoire, possibly interfering with their ability to migrate and accumulate into tumor nest [114]. MIF and MUC-16 glycoprotein, expressed in ovarian tumor, are able to down-regulate NKG2D and to interfere with the formation of the synapses between tumor and NK cells $[115,116]$. In addition, shedding of MIC-A (NKG2D ligand) or of BAT3/BAG6 and B7H6 (ligands of NKp30), is a tumor escape mechanisms commonly reported $[117,118]$. Finally, down-modulation of NK cell activity can also be mediated by inhibitory signals triggered by the engagement of NKp44 receptor with its ligand proliferating nuclear cell antigen (PCNA) expressed in different tumor types [119].

Hypoxia (a condition which often characterizes tumor tissues) can both favor the selection of tumor cells with increased invasive and metastatic potential and alter the phenotypic and functional features of tumor-infiltrating immune cells. Along this line, we have described that hypoxia can significantly alter both the expression and function of major activating NK receptors, with the remarkable exception of CD16, thus allowing NK cells to maintain their capability of mediating ADCC [120].

\section{TKI-Targeted Therapy Effects on NK Cells in Hematological Malignancies and GIST}

TKI have been the first compounds designed to exert TT and are now a consolidated treatment of $\mathrm{Ph}^{+} \mathrm{CML}$ and $\mathrm{Ph}^{+}$-acute lymphoblastic leukemia $\left(\mathrm{Ph}^{+} \mathrm{ALL}\right)[121,122]$. Recently, the US Food and Drug Administration (FDA) approved gilteritinib (Xospata ${ }^{\circledR}$, Astellas Pharma inc., Tokyo, Japan), an FMS-like TK3-internal tandem duplication (FLT3-ITD) inhibitor, for the treatment of relapse/refractory AML [123, 124]. Ph-myeloproliferative neoplasms (MPN) often harbor gain-of-function mutations that result in a V617F amino acid change in the JAK2 protein, mediating constitutive activation of the JAK/STAT (signal transducer and activator of transcription) pathway $[125,126]$. Ruxolitinib (Jakavi, ${ }^{\circledR}$, Novartis, Basilea, Switzerland) is an JAK inhibitor already approved for the treatment of myelofibrosis and polycythemia vera [126].

TKIs such as imatinib mesylate (Gleevec ${ }^{\circledR}$ Novartis, Basilea, Switzerland), nilotinib (Tasigna ${ }^{\circledR}, \mathrm{C}$ Novartis, Basilea, Switzerland), and dasatinib (Sprycel ${ }^{\circledR}$ Bristol-Myers Squibb, New York, NY, USA) are used as the front-line therapy in $\mathrm{Ph}^{+} \mathrm{CML}$ and $\mathrm{Ph}^{+} \mathrm{ALL}$; only Imatinib has also been approved for the first-line therapy of GIST, characterized by c-KIT and PDGFRA mutations $[127,128]$, renal cell carcinoma (RCC) and epidermal growth factor receptor (EGFR) mutation-positive non small cell 
lung cancer (NSCLC) [129,130]. TKIs inhibit the signal transduction pathways of aberrant tyrosin kinases p210 and p190 encoded by the aberrant fusion gene Breakpoint cluster region protein/Abelson murine leukemia viral oncogene homolog 1 (BCR/ABL) which favor blasts proliferation, apoptosis inhibition, and response to regulation factors [131].These drugs can inhibit several targets such as c-KIT, Platelet-derived growth factor (PDGF) but only dasatinib interferes also with ephrin receptor (EPH) and Src kinase that are overexpressed on tumor cells. In particular, dasatinib is capable of crossing the blood brain barrier and acts on brain metastases caused by $\mathrm{Ph}^{+}$LLA. Tyrosin kinase inhibitory drug therapy is not curative: some $50-60 \%$ of patients can develop resistance to the first generation imatinib and to the second generation TKI after imatinib failure. Ponatinib (Iclusig ${ }^{\circledR}$, ARIAD Pharmaceuticals, Inc., Cambridge, MA, USA) a third generation TKI, has been designed for the treatment of $\mathrm{Ph}^{+} \mathrm{ALL}$ and $\mathrm{Ph}^{+} \mathrm{CML}$ with T315I mutation [132]. Ruxolitinib is supposed to also be not curative, but it leads to an excellent symptom control in MPN patients. However, therapeutic effects seem independent from mutational status suggesting a profound modification of inflammatory tumor microenvironment.

TT agents have been approved also for the treatment of $\mathrm{CD} 20^{+} \mathrm{B}$ lymphoid malignancies such as CLL and mantle cell lymphoma. In CLL, agents like the Bruton's tyrosine kinase (BTK) inhibitor ibrutinib (Imbruvica ${ }^{\circledR}$, Johnson \& Johnson, New Brunswick, NJ, USA) and B-cell lymphoma 2 (Bcl-2) inhibitor venetoclax (Venclyxto ${ }^{\circledR}$, AbbVie, North Chicago, IL, USA)are highly effective in CLL and induce deep remissions $[133,134]$. However, also these agents require a continuous treatment and may lose their efficacy upon acquisition of mutations by tumor cells $[135,136]$.

Cumulative evidences indicated that the immune system would play a key role in the success of TKI therapy and in the control of emerging escape mutations that could lead to relapse. TKI therapy not only has a direct effect on onco-protein kinases but also has a key role in restoration of effector cells-mediated immune response such as NK cells, cytotoxic T lymphocytes (CTL) -CD8 and DCs (Figure 2). In vitro and in vivo studies revealed that TKI show the direct and indirect immunomodulatory effects involving natural killer (NK) cells, in particular in patients treated for CML or for GIST tumors [137-139]. On the other hand, the use of JAK inhibitors such as ruxolitinib showed a general dampening of immune response, also on NK cells, both in vitro and in vivo, offering an explanation of increase infections rate and of long term sides effects $[140,141]$. Regarding CLL, analyses of ibrutinib-mediated effects on NK cell proliferation and functions are limited: Kohrt and colleagues showed that ibrutinib inhibits NK cell proliferation, TNF- $\alpha$ production and lead to an anti-CD20-mediated ADCC impairment against chronic lymphocytic leukemia blasts mediated by rituximab [142].

In vitro analyses on the direct effects of imatinib, nilotinib and dasatinib reported conflicting results on NK cell proliferation and functions [137]. It has been described that the addition of Imatinib in co-cultures with NK cells and primary Chronic myeloid leukemia blasts didn't impair NK cell cytotoxicity, while it was observed a significant reduction of IFN- $\gamma$ production in the presence of nilotinib and dasatinib. In particular, dasatinib inhibited MAPK activation pathway involved in NK cell proliferation and activity. Moreover, it should take into account that TKI would favor leukemic blast escape from NK cell-mediated immunosurveillance because of they may induce surface modulation of MIC-A/B on leukemic blasts [143]. The bone marrow (BM) microenvironment plays a crucial role not only in favoring the resistance of leukemic stem cell (LSC) [144] to therapy but also in hematopoietic stem cell differentiation. It has been suggested that low dose of Imatinib has stimulatory effects on hematopoiesis [145], however, it is not clear whether chronic exposure to TKI may modulate cytotoxic lymphocytes maturation. In this context, we analyzed whether TKI treatment may influence NK cell differentiation and repertoire. The results suggested that dasatinib skews in vitro human $\mathrm{CD}_{56}{ }^{+}$innate lymphoid cells differentiation from $\mathrm{CD} 34^{+}$hematopoietic stem cells towards non-cytotoxic Innate lymphoid cells type 3 (ILC3). The few NK cells undergoing in vitro differentiation in the presence of dasatinib express higher percentages of IFN- $\gamma$ but had a reduced cytolytic activity against K562 leukemic cell line [146]. 
A

POSITIVE EFFECTS
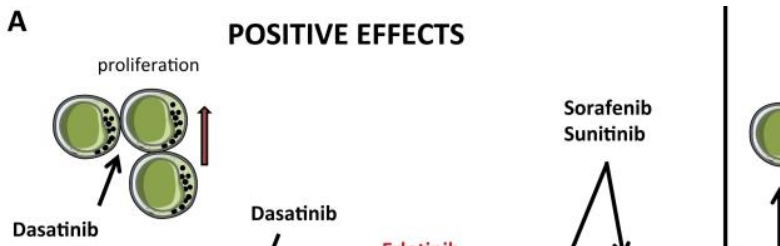

NEGATIVE EFFECTS

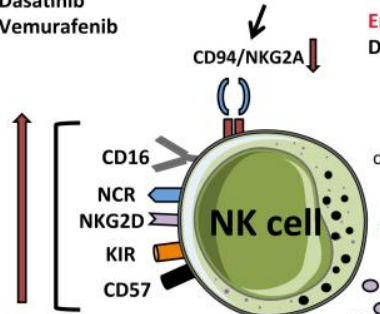

Dasatinib

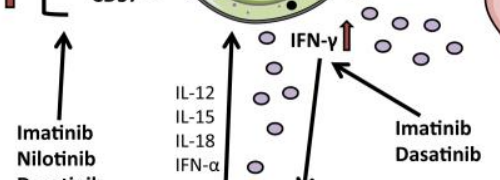

00

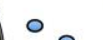

00

Nilotinib

Dasatinib

IFN- $\alpha \circ \downarrow$ Dasatinib
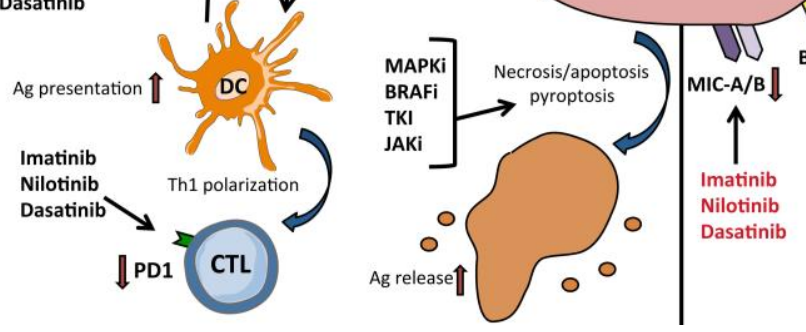
patients undergoing TKI therapy (imatinib, nilotinib and dasatinib), revealed that early lymphocytes mobilization was associated with early molecular response [151].

Ex-vivo detailed phenotypic analyses on NK cell repertoire were lacking for long time. One report provided a short description of a comparative analysis among patients treated with different TKI [152]. Data indicated that imatinib-treated patients displayed on PB-NK cells an increased expression of the main activating receptors (NCR and NKG2D) while dasatinib patients showed an increased expression of KIR2DL1. Recently, a longitudinal study of 88 CML patients showed that dasatinib induced down-regulation of NKG2A on PB NK cells, leading to enhanced cytotoxicity and favoring CML patients' clinical response. This effect wasn't detectable in nilotinib- or imatinib- treated patients: in vitro experiments suggested that dasatinib inactivated p38 mitogen-activated protein kinase (MAPK) affecting nuclear distribution of GATA Binding Protein 3 (GATA3) which is involved in regulation of NKG2A transcription [153]. Finally, Hughes et al. demonstrated that CML patients in major molecular response (MMR) have an increase of $\mathrm{CD} 56^{+} \mathrm{CD} 94 / \mathrm{NKG} 2 \mathrm{C}^{+} \mathrm{NKG} 2 \mathrm{D}^{+} \mathrm{NCR}^{+} \mathrm{KIR}^{+} \mathrm{NK}$ cells as compared to diagnosis, consistent with the restoration of a PB-NK cell repertoire typical of healthy individuals. Of note, authors observed a parallel decrease of MDSC, T-regs and of $\mathrm{CD} 3^{+} \mathrm{PD}-1^{+} \mathrm{T}$ cells confirming that molecular response require a global effect on immune cell repertoire restoration, thus suggesting the possibility that combined therapy that would include TKI and the use of immune check point inhibitors for CTLA-4 and/or PD-1 pathway might increase the number of patients achieving MMR [154].

All these evidences provide important clues to identify biomarkers that could help to define CML patients with better prognosis and eligible for a successful therapy discontinuation. Indeed, a high rate of CML patients achieve a deep molecular response (DMR, BCR-ABL $\leq 0.1 \%$ ), but there are many concerns regarding the long-term sides effects of TKI therapy, and the economic burden of these therapies. Thus, one of the major goals is actually the possibility to induce a durable DMR ( $\geq 2$ years) to allow a successful treatment free remission (TFR) $[6,155,156]$. In this context, the achievement of a rapid, durable and deep DMR seems to be crucial, thus, the contribution of immune system in this could play an important role $[157,158]$. Two reports suggested an increase of mature CD56 ${ }^{+} \mathrm{CD} 57^{+} \mathrm{CD}^{2} \mathrm{~L}^{-} \mathrm{NK}$ cell numbers in CML patients $\mathrm{PB}$, that was associated with successful Imatinib discontinuation and deep molecular response in dasatinib treated patients [159,160]. In IMMUNOSTIM clinical trial, after imatinib treatment cessation, non-relapsing patients had a significantly increase of cytotoxic CD56 $\mathrm{dim}$, which was maintained over time, as compared to patients relapsing [161]. On the other hand, another study analyzed immune response in patients who, after DMR achievement with any TKI, underwent 2 years consolidation therapy with dasatinib and then discontinued treatment. Researchers found that patients who displayed higher percentages of PB-NK cells during TKI treatment had a higher DMR rate achievement. However, once started dasatinib consolidation treatment, a specific transient increase of circulating $\mathrm{CD} 66^{+} \mathrm{CD} 57^{+} \mathrm{NK}$ cell percentages was unfavorable and associated to a rapid molecular relapse after therapy discontinuation [162]. The possible mechanisms explaining this phenomenon were not clear and a more detailed analyses of the PB or BM NK cells could have been be useful to address this issue.

Beyond the general positive effect that TKI therapy may directly exert in vivo on immune cell recovering and functional restoration, it is conceivable that patient's genetic features may contribute to identify markers predictors for TKI therapy. It has been described a possible role of NK polymorphic patterns of KIR receptors to predict TFR in CML patients [163]. The absence of KIR2DS1, was associated with a better response to imatinib [164]. Yeung et al. observed that KIR2DL5B genotype could predict clinical outcome in CML-treated patients [165].

The clinical implication of TKI therapy in the treatment of solid tumor improved overall survival, reducing use of classical chemotherapy. Few studies in solid tumor regarding TKI modulation of NK response in vivo were performed, most of them on GIST patients. Imatinib achieves disease control in $80 \%$ of advanced KIT-expressing GIST, with median progression-free survival of 20-24 months [128]. In GIST patients treated with imatinib at 12 months, it has been observed an increase of IFN- $\gamma$ production mediated by NKp30 and NKG2D receptor on NK cells. The IFN- $\gamma$ production from 
circulating NK cells after 2 months of imatinib treatment could be correlated with long-term survival in GIST patients [166]. The prolonged treatment with imatinib lead to decrease of MIC-A/B on GIST and an increase of $\mathrm{NKp} 46^{+} \mathrm{NK}$ cells infiltration into tumor core associating with a reduced relapse [93]. Of note, also in these patients it has been possible to discriminate between an improved NK cell response associated with imatinib treatment and the genetic profile of patients NK cell repertoire that can be predictive of a more favorable clinical outcome. In particular, the different expression of NKp30 isoforms and the presence of NKp30 soluble ligands sB7-H6/BAG6, are predictive biomarkers of response to imatinib in GIST patients [167].

\section{Targeted Therapies and Their Immunomodulatory Effects on NK Cells in Solid Tumors}

In the last 15 years, beyond the use of TKI such as imatinib in neuroblastoma and GIST patients, solid tumor treatment therapy took advantage by the identification of novel agents targeting oncoproteins frequently expressed in several malignancies. In this context, the MAPK cascade is perhaps the most important oncogenic driver of human cancers [3]. Approximately $50 \%$ of cutaneous melanomas harbor the oncogenic $B R A F^{V 600}$ mutation that constitutively activates the mitogen-activated protein kinase (MAPK)/ERK-signaling pathway [168]. BRAF-mutation has subsequently been identified as a driver mutation in several other cancers (colon cancer, thyroid cancer, and hairy cell leukemia) [168-170]. Constitutive activation of the MAPK signaling pathway is involved in tumor progression including evasion of apoptosis, unchecked cell replication, neoangiogenesis, tissue invasion, metastasis as well as escape from immune response [171]. In 2008, BRAF-targeted therapies for melanoma were tested in clinical trials demonstrating high response rates (more than 70\%) [172] and a significant increase in survival when compared to dacarbazine that led to the FDA approval of vemurafenib (PLX4032, Zelboraf ${ }^{\circledR}$, Plexxikon, Berkeley, CA, USA) in 2011 [173].

Although treatment with vemurafenib greatly improved the control of metastatic melanoma progression clinical responses were limited in time (less than 12 months) in most patients [174]. The emergence of resistance may reflect reactivation of MAPK pathway due to new mutations, BRAF amplification, or activation of alternative pathways involving MAPK and PI3K/Akt [175]. In view of these limitations, new protocols have been designed in which BRAF-targeted therapies have been associated with MEK inhibitors (MEK-i), such as trametinib [176] or cobimetinib [177]. However, again an important limitation these combination strategies is that patients still progress within a year [176].

Several other TT have been designed and approved for the treatment of different malignancies. Sunitinib (Sutent ${ }^{\circledR}$, Pfizer, New York, NY, USA), sorafenib (Nexavar ${ }^{\circledR}$, Bayer, Leverkusen, Germany)and alectinib (Alecensa ${ }^{\circledR}$, Chugai Pharmaceutical, Tokyo, Japan) are involved in the inhibition of different kinases like vascular endothelial growth factor receptor (VEGFR), fibroblast growth factor receptors (FGFR), FLT3, proto-oncogene rearranged during transfection (RET). In particular, sunitinib was developed for the treatment of GIST, advanced metastatic renal cell carcinoma (MRCC) and primitive neuro-ectodermal tumor (pNET). Sorafenib, used for the treatment of HCC, inhibits serin/threonine kinases such as BRAF, CRAF BRAF V600E and ERK1/2, while alectinib was developed to treat anaplastic lymphoma kinase (ALK)-positive NSCLC. Gefitinib (Iressa ${ }^{\circledR}$, AstraZeneca, London, United Kingdom) and erlotinib (Tarceva ${ }^{\circledR}$, AstraZeneca, London, United Kingdom) are similar drugs that inhibit EGFR in metastatic NSCLC with EGFR-TK activating mutation [3].

The increase of compounds available for TT therapy produced large number of studies however, the most detailed analyses have been performed on MAPK pathway activation which is an important therapeutic target, particularly in melanoma. Differently from hematological malignancies it is not clear whether the emergence of resistance could be related also to an immunomodulatory effect exerted on tumor immunosurveillance. Indeed, these inhibitors may exert bystander effects on certain immune cells that depend on MAPK for their activation and/or proliferation. TT would play a crucial role acting directly on the tumor by inducing its senescence, triggering the release of antigenic debris, thus favoring the acquisition by tumor cells of immunostimulatory properties and a more "permissive tumor microenvironment" that restore antitumor immune response, including that one of NK cells 
(Figure 2) [8]. On the other hand, they could exert an inhibitory effect acting on the lymphocyte activation pathways orchestrated by MAPK. Thus, it would be crucial to clarify these effects. However, while there are several in vitro data on the effect on immune cells and in particular on NK cells, data derived from ex-vivo analyses on patients undergoing BRAF-i/MEK-i TT are limited.

Accumulating evidences indicated that inhibition of the MAPK pathway in melanoma cells may result in the block of the production of tumor-derived immunosuppressive or pro-angiogenetic factors including IL-6, IL-10 and VEGF that are essential for cancer immune evasion and growth [178]. Several studies in mice suggested an improvement of NK cell response against tumors during BRAF-i therapy $[179,180]$. In humans, we showed that PLX4032, a selective BRAF-i, has no inhibitory in vitro effect either on NK cell phenotype (i.e., activating NK receptor expression) proliferation in response to cytokines (including IL-2, IL-15, and IL-18) or on NK cell functions [181]. Furthermore, PLX4720 (a research analogue of vemurafenib) increased pERK1/2, CD69 expression and IFN- $\gamma$ release in human NK cell cultures exposed to IL-2 and triggered via NKp30 [180]. Finally, it has been demonstrated that circulating NK cell numbers were even increased in vemurafenib-treated patients [182].

On the other hand, MAPKi, developed to block aberrantly activated pathways in melanoma cells, can have unexpected effects by concomitantly blocking the same pathway in TI-immune cells. Indeed, MEKi have been shown to have immunosuppressive properties on NK cells and to block NK-mediated antitumor immune response. MEK-i PD0325901 strongly inhibited the surface expression of the main activating receptors and the anti-tumor activity of freshly isolated NK cells cultured with IL-2 or IL-15 while no functional inhibition occurred in NK cells exposed to a combination of IL-15 and IL-18, suggesting that IL-15 and IL-18 cytokines could be utilized in combination with MEK inhibitors to rescue NK cell anti-tumor potential in vivo, while in IL-15/IL-18-untreated and in BRAFi-treated NK cells only a small fraction of cells expressed CD16, the large majority of IL-15/IL-18 MEKi-treated cells expressed of this marker, thus allowing MEKi-treated NK cells to preserve their capability of mediating antibody-dependent cell cytotoxicity (ADCC).

Interestingly, BRAF/MEK inhibitors have no effect when added to NK cells pre-activated with IL-2 or IL-15, thus offering an important clue for the development of novel therapeutic strategies combining these kinase-targeted agents with adoptive NK cell therapy [181]. Data regarding other tyrosine kinase inhibitors are limited, but it seems that they may exert an inhibitory rather than stimulatory effect on NK cells. Sorafenib has been systemically utilized in the therapy of the advanced HCC. Although it leads to a significant block of tumor progression, it affects the function of NK cells including proliferation (due to the blocking of the PI3K/AKT pathway), production of effector molecules (such as perforin and granzyme B), cytokines (including TNF- $\alpha$ and IFN- $\gamma$ ) and NK-cell mediated cytotoxicity in response to tumor targets, due to impaired ERK phosphorylation [183]. Other kinase inhibitors such as those targeting JAK involved in the signaling cascade of cytokine receptors, may influence NK cells [184]. Despite the JAK/STAT pathway is an attractive target for breast cancer therapy due to its frequent activation in breast metatasis, a clinical trial evaluating JAK inhibitors (JAKi, ruxolitinib) in advanced breast cancer failed (NCT01562873). In vitro, ruxolitinib treatment blocked STAT phosphorylation and strongly decreased both proliferation of NK cells and the killing capability of NK cells against carcinoma cells, indicating that JAK/STAT pathway inhibition impairs the anti-tumor potential of NK cells.

In addition, TT may interfere with the NK/target interactions through modulation of NK ligands on cancer cells. In vitro treatment of human melanoma cell lines with vemurafenib downregulated the expression of NKp30L (B7H6) and NKG2DL (MICA and ULBPs) thus reducing their immunogenicity to NK cells $[185,186]$. By contrast erlotinib, an EGFR tyrosine kinase inhibitor widely used for the treatment of NSCLC patients, significantly modulates in vitro the phenotype of lung cancer cell lines toward a more epithelial ones and promotes tumor sensitivity to NK-mediated lysis by restoring susceptibility to caspase-dependent pathways [187].

Taken together these studies highlight the importance of evaluating the effect of TT on NK cell function and NK/tumor crosstalk to prevent potential harmful bystander effect. 


\section{Conclusions}

Targeted therapy can arrest tumor progression and induce a sharp regression in patients bearing specific mutations. In hematological malignancies, cumulative evidences indicate that TKI may induce durable response and support the hypothesis that this achievement correlates with the restoration of immune response that would counteract the emergence of mutations that could lead to resistance and relapse. On the other hand, data on solid tumors suggest that TT is not able to achieve a long-lasting remission. Moreover, in solid tumor, the effects of TT treatment on immune system still report conflicting results. Thus, additional treatment options are necessary and the combination with immunotherapy may represent the most suitable one. Targeted therapy may provide a favorable time interval in which stimulation of immune system by immunotherapy may play a complementary role and elicit an efficient tumor clearance in all patients in which TT alone is not able to induce the restoration of immune response.

Currently, there are several ongoing clinical trials regarding the combination of TT/TKI therapy and other therapies such as pharmacological manipulation of immune response (with type I IFN or lenalidomide), use of (ICI), monoclonal antibodies, vaccines and oncolytic virus that should boost immune response in CP_CML, MRCC, NSCLC, melanoma and other type of cancers $[157,188,189]$. These approaches would provide a durable response in larger cohorts of patients overcoming drug-induced resistance and improving clinical outcome. In CML, current knowledge of the effect of TKI on NK cell recovery in vivo and on the frequency of NK cells in long term TFR patients, prompted to design clinical trials that include the use of type I IFN with nilotinib to enhance immune modulation before TKI therapy discontinuation (NCT02001818), or lenalidomide in combination with different TKI (ACTRN 12615001169538) that specifically should increase NK cell antitumor response. Trials that include the use of ICI (Nivolumab, anti-PD-1) in combination with dasatinib for CML treatment (NCT02011945) or in combination with ibrutinib for CLL (NCT02420912) are also on going. In solid tumors the role of NK cells may appear less relevant, however their activation may support a first line of tumor control by cytolytic activity, IFN- $\gamma$ and TNF-a production, and by stimulating Th1 response through DCs editing $[190,191]$. Several trials with therapy combination are ongoing: NCT01738139 involves patients with different advanced solid malignancies, including GIST, treated with a combination of Imatinib and Ipilimumab (anti-CTLA-4). Similarly, other trials are evaluating the efficacy of the combined use of TT agents (vemurafenib, cobimetinib, sunitinib, erlotinib and others) with ICI (pembrolizumab, anti-PD1, atezolizumab, anti-PDL-1, ipilimumab) in melanoma, NSCLC and RCC [188,189,192]. Several clinical trials exploiting the use of anti_TIGIT/TIM-3 blocking mAbs are also on going, either as monotherapy or mainly in combination with other anti-PD-1 or anti-PDL-1 mAbs while no one in combination with TT agents [193].

Most of these trials are already closed but the results are still under evaluation. However, the recent advances of TT and of immunotherapy on the control of neoplastic disease justify the expectation of promising results. In this context, NK cells may play a key role, representing both an important tool to exploit for the achievement a durable remission and an immunological biomarker, detectable in patients PB sample and tumor biopsies, that might work as prognostic factor of clinical outcome in different cancer patients.

Author Contributions: L.D., S.O., G.P. and C.V. performed bibliographic research and wrote the paper contributing to the different sections. L.D. created figures. M.C.M. revised the paper and contributed to the discussion. Authorship must be limited to those who have contributed substantially to the work reported. All authors have read and agreed to the published version of the manuscript.

Funding: Italian Ministry of Health Id: RF-2016-02362288 (to G.P.); 5X1000 Italian Ministry of Health 2015 and 2016 (to M.C.M.); RC-2019 IRCCS Ospedale Policlinico San Martino (to G.P.). L.D. and S.O. are recipients of fellowships awarded by AIRC.

Conflicts of Interest: All the authors declare they don't have any conflict of interest 


\section{References}

1. Haber, D.A.; Gray, N.S.; Baselga, J. The evolving war on cancer. Cell 2011, 145, 19-24. [CrossRef]

2. Jabbour, E.; Cortes, J.; Ravandi, F.; O'Brien, S.; Kantarjian, H. Targeted therapies in hematology and their impact on patient care: Chronic and acute myeloid leukemia. Semin. Hematol. 2013, 50, 271-283. [CrossRef] [PubMed]

3. Lee, Y.T.; Tan, Y.J.; Oon, C.E. Molecular targeted therapy: Treating cancer with specificity. Eur. J. Pharmacol. 2018, 834, 188-196. [CrossRef] [PubMed]

4. O’Brien, S.G.; Guilhot, F.; Larson, R.A.; Gathmann, I.; Baccarani, M.; Cervantes, F.; Cornelissen, J.J.; Fischer, T.; Hochhaus, A.; Hughes, T.; et al. Imatinib compared with interferon and low-dose cytarabine for newly diagnosed chronic-phase chronic myeloid leukemia. N. Engl. J. Med. 2003, 348, 994-1004. [CrossRef] [PubMed]

5. Tsimberidou, A.M. Targeted therapy in cancer. Cancer Chemother. Pharmacol. 2015, 76, 1113-1132. [CrossRef] [PubMed]

6. Hehlmann, R. Innovation in hematology. Perspectives: CML 2016. Haematologica 2016, 101, 657-659. [CrossRef] [PubMed]

7. Jiang, Q.; Wang, H.; Yu, L.; Gale, R.P. Higher out-of-pocket expenses for tyrosine kinase-inhibitor therapy is associated with worse health-related quality-of-life in persons with chronic myeloid leukemia. J. Cancer Res. Clin. Oncol. 2017, 143, 2619-2630. [CrossRef]

8. Vanneman, M.; Dranoff, G. Combining immunotherapy and targeted therapies in cancer treatment. Nat. Rev. Cancer 2012, 12, 237-251. [CrossRef]

9. Kreutzman, A.; Porkka, K.; Mustjoki, S. Immunodulatory effects of Tyrosine Kinase Inhibitors. In International Trends in Immunity; Research Publisher Inc.: Santa Clara, CA, USA, 2013; Volume 1, pp. 22-32.

10. Moretta, A.; Bottino, C.; Mingari, M.C.; Biassoni, R.; Moretta, L. What is a natural killer cell? Nat. Immunol. 2002, 3, 6-8. [CrossRef]

11. Vivier, E.; Tomasello, E.; Baratin, M.; Walzer, T.; Ugolini, S. Functions of natural killer cells. Nat. Immunol. 2008, 9, 503-510. [CrossRef]

12. Pietra, G.; Vitale, C.; Pende, D.; Bertaina, A.; Moretta, F.; Falco, M.; Vacca, P.; Montaldo, E.; Cantoni, C.; Mingari, M.C.; et al. Human natural killer cells: News in the therapy of solid tumors and high-risk leukemias. Cancer Immunol. Immunother. 2016, 65, 465-476. [CrossRef] [PubMed]

13. Cantoni, C.; Huergo-Zapico, L.; Parodi, M.; Pedrazzi, M.; Mingari, M.C.; Moretta, A.; Sparatore, B.; Gonzalez, S.; Olive, D.; Bottino, C.; et al. NK Cells, Tumor Cell Transition, and Tumor Progression in Solid Malignancies: New Hints for NK-Based Immunotherapy? J. Immunol. Res. 2016, 2016, 4684268. [CrossRef] [PubMed]

14. Chen, Z.; Yang, Y.; Liu, L.L.; Lundqvist, A. Strategies to Augment Natural Killer (NK) Cell Activity against Solid Tumors. Cancers 2019, 11, 1040. [CrossRef] [PubMed]

15. Vivier, E.; Raulet, D.H.; Moretta, A.; Caligiuri, M.A.; Zitvogel, L.; Lanier, L.L.; Yokoyama, W.M.; Ugolini, S. Innate or adaptive immunity? The example of natural killer cells. Science 2011, 331, 44-49. [CrossRef]

16. Chiossone, L.; Dumas, P.Y.; Vienne, M.; Vivier, E. Natural killer cells and other innate lymphoid cells in cancer. Nat. Rev. Immunol. 2018, 18, 671-688. [CrossRef]

17. Voskoboinik, I.; Whisstock, J.C.; Trapani, J.A. Perforin and granzymes: Function, dysfunction and human pathology. Nat. Rev. Immunol. 2015, 15, 388-400. [CrossRef]

18. Fauriat, C.; Long, E.O.; Ljunggren, H.G.; Bryceson, Y.T. Regulation of human NK-cell cytokine and chemokine production by target cell recognition. Blood 2010, 115, 2167-2176. [CrossRef]

19. Caligiuri, M.A. Human natural killer cells. Blood 2008, 112, 461-469. [CrossRef]

20. Carrega, P.; Ferlazzo, G. Natural killer cell distribution and trafficking in human tissues. Front. Immunol. 2012, 3, 347. [CrossRef]

21. Moretta, A. Natural killer cells and dendritic cells: Rendezvous in abused tissues. Nat. Rev. Immunol. 2002, 2, 957-964. [CrossRef]

22. Riise, R.E.; Bernson, E.; Aurelius, J.; Martner, A.; Pesce, S.; Della Chiesa, M.; Marcenaro, E.; Bylund, J.; Hellstrand, K.; Moretta, L.; et al. TLR-Stimulated Neutrophils Instruct NK Cells To Trigger Dendritic Cell Maturation and Promote Adaptive T Cell Responses. J. Immunol. 2015, 195, 1121-1128. [CrossRef] [PubMed] 
23. Sun, H.; Sun, C.; Tian, Z.; Xiao, W. NK cells in immunotolerant organs. Cell Mol. Immunol. 2013, 10, $202-212$. [CrossRef] [PubMed]

24. Moretta, L.; Bottino, C.; Pende, D.; Vitale, M.; Mingari, M.C.; Moretta, A. Different checkpoints in human NK-cell activation. Trends Immunol. 2004, 25, 670-676. [CrossRef] [PubMed]

25. Lopez-Botet, M.; Perez-Villar, J.J.; Carretero, M.; Rodriguez, A.; Melero, I.; Bellon, T.; Llano, M.; Navarro, F. Structure and function of the CD94 C-type lectin receptor complex involved in recognition of HLA class I molecules. Immunol. Rev. 1997, 155, 165-174. [CrossRef]

26. Braud, V.M.; Allan, D.S.; O'Callaghan, C.A.; Soderstrom, K.; D'Andrea, A.; Ogg, G.S.; Lazetic, S.; Young, N.T.; Bell, J.I.; Phillips, J.H.; et al. HLA-E binds to natural killer cell receptors CD94/NKG2A, B and C. Nature 1998, 391, 795-799. [CrossRef]

27. Long, E.O. Regulation of immune responses through inhibitory receptors. Annu. Rev. Immunol. 1999, 17, 875-904. [CrossRef]

28. Anfossi, N.; Andre, P.; Guia, S.; Falk, C.S.; Roetynck, S.; Stewart, C.A.; Breso, V.; Frassati, C.; Reviron, D.; Middleton, D.; et al. Human NK cell education by inhibitory receptors for MHC class I. Immunity 2006, 25, 331-342. [CrossRef]

29. Moretta, A.; Bottino, C.; Vitale, M.; Pende, D.; Cantoni, C.; Mingari, M.C.; Biassoni, R.; Moretta, L. Activating receptors and coreceptors involved in human natural killer cell-mediated cytolysis. Annu. Rev. Immunol. 2001, 19, 197-223. [CrossRef]

30. Bottino, C.; Castriconi, R.; Moretta, L.; Moretta, A. Cellular ligands of activating NK receptors. Trends Immunol. 2005, 26, 221-226. [CrossRef]

31. Kruse, P.H.; Matta, J.; Ugolini, S.; Vivier, E. Natural cytotoxicity receptors and their ligands. Immunol. Cell Biol. 2014, 92, 221-229. [CrossRef]

32. Parodi, M.; Favoreel, H.; Candiano, G.; Gaggero, S.; Sivori, S.; Mingari, M.C.; Moretta, L.; Vitale, M.; Cantoni, C. NKp44-NKp44 Ligand Interactions in the Regulation of Natural Killer Cells and Other Innate Lymphoid Cells in Humans. Front. Immunol. 2019, 10, 719. [CrossRef]

33. Raulet, D.H. Roles of the NKG2D immunoreceptor and its ligands. Nat. Rev. Immunol. 2003, 3, 781-790. [CrossRef] [PubMed]

34. Meinke, S.; Watzl, C. NK cell cytotoxicity mediated by 2B4 and NTB-A is dependent on SAP acting downstream of receptor phosphorylation. Front. Immunol. 2013, 4, 3. [CrossRef] [PubMed]

35. Welte, S.; Kuttruff, S.; Waldhauer, I.; Steinle, A. Mutual activation of natural killer cells and monocytes mediated by NKp80-AICL interaction. Nat. Immunol. 2006, 7, 1334-1342. [CrossRef] [PubMed]

36. Kim, N.; Kim, H.S. Targeting Checkpoint Receptors and Molecules for Therapeutic Modulation of Natural Killer Cells. Front. Immunol. 2018, 9, 2041. [CrossRef] [PubMed]

37. Sanchez-Correa, B.; Valhondo, I.; Hassouneh, F.; Lopez-Sejas, N.; Pera, A.; Bergua, J.M.; Arcos, M.J.; Banas, H.; Casas-Aviles, I.; Duran, E.; et al. DNAM-1 and the TIGIT/PVRIG/TACTILE Axis: Novel Immune Checkpoints for Natural Killer Cell-Based Cancer Immunotherapy. Cancers 2019, 11, 877. [CrossRef]

38. Ndhlovu, L.C.; Lopez-Verges, S.; Barbour, J.D.; Jones, R.B.; Jha, A.R.; Long, B.R.; Schoeffler, E.C.; Fujita, T.; Nixon, D.F.; Lanier, L.L. Tim-3 marks human natural killer cell maturation and suppresses cell-mediated cytotoxicity. Blood 2012, 119, 3734-3743. [CrossRef]

39. Bryceson, Y.T.; Ljunggren, H.G.; Long, E.O. Minimal requirement for induction of natural cytotoxicity and intersection of activation signals by inhibitory receptors. Blood 2009, 114, 2657-2666. [CrossRef]

40. Bryceson, Y.T.; March, M.E.; Barber, D.F.; Ljunggren, H.G.; Long, E.O. Cytolytic granule polarization and degranulation controlled by different receptors in resting NK cells. J. Exp. Med. 2005, 202, 1001-1012. [CrossRef]

41. Moretta, A.; Sivori, S.; Vitale, M.; Pende, D.; Morelli, L.; Augugliaro, R.; Bottino, C.; Moretta, L. Existence of both inhibitory (p58) and activatory (p50) receptors for HLA-C molecules in human natural killer cells. J. Exp. Med. 1995, 182, 875-884. [CrossRef]

42. Chewning, J.H.; Gudme, C.N.; Hsu, K.C.; Selvakumar, A.; Dupont, B. KIR2DS1-positive NK cells mediate alloresponse against the C2 HLA-KIR ligand group in vitro. J. Immunol. 2007, 179, 854-868. [CrossRef] [PubMed] 
43. Beziat, V.; Liu, L.L.; Malmberg, J.A.; Ivarsson, M.A.; Sohlberg, E.; Bjorklund, A.T.; Retiere, C.; Sverremark-Ekstrom, E.; Traherne, J.; Ljungman, P.; et al. NK cell responses to cytomegalovirus infection lead to stable imprints in the human KIR repertoire and involve activating KIRs. Blood 2013, 121, 2678-2688. [CrossRef] [PubMed]

44. Guma, M.; Budt, M.; Saez, A.; Brckalo, T.; Hengel, H.; Angulo, A.; Lopez-Botet, M. Expansion of CD94/NKG2C + NK cells in response to human cytomegalovirus-infected fibroblasts. Blood 2006, 107, 3624-3631. [CrossRef] [PubMed]

45. Foley, B.; Cooley, S.; Verneris, M.R.; Pitt, M.; Curtsinger, J.; Luo, X.; Lopez-Verges, S.; Lanier, L.L.; Weisdorf, D.; Miller, J.S. Cytomegalovirus reactivation after allogeneic transplantation promotes a lasting increase in educated NKG2C + natural killer cells with potent function. Blood 2012, 119, 2665-2674. [CrossRef]

46. Graef, T.; Moesta, A.K.; Norman, P.J.; Abi-Rached, L.; Vago, L.; Older Aguilar, A.M.; Gleimer, M.; Hammond, J.A.; Guethlein, L.A.; Bushnell, D.A.; et al. KIR2DS4 is a product of gene conversion with KIR3DL2 that introduced specificity for HLA-A*11 while diminishing avidity for HLA-C. J. Exp. Med. 2009, 206, 2557-2572. [CrossRef]

47. Carrega, P.; Bonaccorsi, I.; Di Carlo, E.; Morandi, B.; Paul, P.; Rizzello, V.; Cipollone, G.; Navarra, G.; Mingari, M.C.; Moretta, L.; et al. CD56(bright)perforin(low) noncytotoxic human NK cells are abundant in both healthy and neoplastic solid tissues and recirculate to secondary lymphoid organs via afferent lymph. J. Immunol. 2014, 192, 3805-3815. [CrossRef]

48. Bjorkstrom, N.K.; Riese, P.; Heuts, F.; Andersson, S.; Fauriat, C.; Ivarsson, M.A.; Bjorklund, A.T.; Flodstrom-Tullberg, M.; Michaelsson, J.; Rottenberg, M.E.; et al. Expression patterns of NKG2A, KIR, and CD57 define a process of CD56dim NK-cell differentiation uncoupled from NK-cell education. Blood 2010, 116, 3853-3864. [CrossRef]

49. De Maria, A.; Bozzano, F.; Cantoni, C.; Moretta, L. Revisiting human natural killer cell subset function revealed cytolytic CD56(dim)CD16+ NK cells as rapid producers of abundant IFN-gamma on activation. Proc. Natl. Acad. Sci. USA 2011, 108, 728-732. [CrossRef]

50. Trinchieri, G. Biology of natural killer cells. Adv. Immunol. 1989, 47, 187-376. [CrossRef]

51. Pende, D.; Rivera, P.; Marcenaro, S.; Chang, C.C.; Biassoni, R.; Conte, R.; Kubin, M.; Cosman, D.; Ferrone, S.; Moretta, L.; et al. Major histocompatibility complex class I-related chain A and UL16-binding protein expression on tumor cell lines of different histotypes: Analysis of tumor susceptibility to NKG2D-dependent natural killer cell cytotoxicity. Cancer Res. 2002, 62, 6178-6186.

52. Pende, D.; Spaggiari, G.M.; Marcenaro, S.; Martini, S.; Rivera, P.; Capobianco, A.; Falco, M.; Lanino, E.; Pierri, I.; Zambello, R.; et al. Analysis of the receptor-ligand interactions in the natural killer-mediated lysis of freshly isolated myeloid or lymphoblastic leukemias: Evidence for the involvement of the Poliovirus receptor (CD155) and Nectin-2 (CD112). Blood 2005, 105, 2066-2073. [CrossRef]

53. Carbone, E.; Neri, P.; Mesuraca, M.; Fulciniti, M.T.; Otsuki, T.; Pende, D.; Groh, V.; Spies, T.; Pollio, G.; Cosman, D.; et al. HLA class I, NKG2D, and natural cytotoxicity receptors regulate multiple myeloma cell recognition by natural killer cells. Blood 2005, 105, 251-258. [CrossRef]

54. Cebo, C.; Da Rocha, S.; Wittnebel, S.; Turhan, A.G.; Abdelali, J.; Caillat-Zucman, S.; Bourhis, J.H.; Chouaib, S.; Caignard, A. The decreased susceptibility of Bcr/Abl targets to NK cell-mediated lysis in response to imatinib mesylate involves modulation of NKG2D ligands, GM1 expression, and synapse formation. J. Immunol. 2006, 176, 864-872. [CrossRef]

55. Schlegel, P.; Ditthard, K.; Lang, P.; Mezger, M.; Michaelis, S.; Handgretinger, R.; Pfeiffer, M. NKG2D Signaling Leads to NK Cell Mediated Lysis of Childhood AML. J. Immunol. Res. 2015, 2015, 473175. [CrossRef]

56. Carlsten, M.; Baumann, B.C.; Simonsson, M.; Jadersten, M.; Forsblom, A.M.; Hammarstedt, C.; Bryceson, Y.T.; Ljunggren, H.G.; Hellstrom-Lindberg, E.; Malmberg, K.J. Reduced DNAM-1 expression on bone marrow NK cells associated with impaired killing of CD34+ blasts in myelodysplastic syndrome. Leukemia 2010, 24, 1607-1616. [CrossRef]

57. Godal, R.; Bachanova, V.; Gleason, M.; McCullar, V.; Yun, G.H.; Cooley, S.; Verneris, M.R.; McGlave, P.B.; Miller, J.S. Natural killer cell killing of acute myelogenous leukemia and acute lymphoblastic leukemia blasts by killer cell immunoglobulin-like receptor-negative natural killer cells after NKG2A and LIR-1 blockade. Biol. Blood Marrow Transplant. J. Am. Soc. Blood Marrow Transplant. 2010, 16, 612-621. [CrossRef] 
58. Marcenaro, E.; Carlomagno, S.; Pesce, S.; Della Chiesa, M.; Moretta, A.; Sivori, S. Role of alloreactive KIR2DS1(+) NK cells in haploidentical hematopoietic stem cell transplantation. J. Leukoc. Biol. 2011, 90, 661-667. [CrossRef]

59. Venstrom, J.M.; Dupont, B.; Hsu, K.C.; Pittari, G.; Gooley, T.A.; Chewning, J.H.; Spellman, S.; Haagenson, M.; Gallagher, M.M.; Malkki, M.; et al. Donor activating KIR2DS1 in leukemia. N. Engl. J. Med. 2014, 371, 2042. [CrossRef]

60. Verfaillie, C.; Kay, N.; Miller, W.; McGlave, P. Diminished A-LAK cytotoxicity and proliferation accompany disease progression in chronic myelogenous leukemia. Blood 1990, 76, 401-408. [CrossRef]

61. Pierson, B.A.; Miller, J.S. CD56+bright and CD56+dim natural killer cells in patients with chronic myelogenous leukemia progressively decrease in number, respond less to stimuli that recruit clonogenic natural killer cells, and exhibit decreased proliferation on a per cell basis. Blood 1996, 88, 2279-2287. [CrossRef]

62. Kiladjian, J.J.; Bourgeois, E.; Lobe, I.; Braun, T.; Visentin, G.; Bourhis, J.H.; Fenaux, P.; Chouaib, S.; Caignard, A. Cytolytic function and survival of natural killer cells are severely altered in myelodysplastic syndromes. Leukemia 2006, 20, 463-470. [CrossRef]

63. Costello, R.T.; Sivori, S.; Marcenaro, E.; Lafage-Pochitaloff, M.; Mozziconacci, M.J.; Reviron, D.; Gastaut, J.A.; Pende, D.; Olive, D.; Moretta, A. Defective expression and function of natural killer cell-triggering receptors in patients with acute myeloid leukemia. Blood 2002, 99, 3661-3667. [CrossRef]

64. Fauriat, C.; Moretta, A.; Olive, D.; Costello, R.T. Defective killing of dendritic cells by autologous natural killer cells from acute myeloid leukemia patients. Blood 2005, 106, 2186-2188. [CrossRef]

65. Khaznadar, Z.; Boissel, N.; Agaugue, S.; Henry, G.; Cheok, M.; Vignon, M.; Geromin, D.; Cayuela, J.M.; Castaigne, S.; Pautas, C.; et al. Defective NK Cells in Acute Myeloid Leukemia Patients at Diagnosis Are Associated with Blast Transcriptional Signatures of Immune Evasion. J. Immunol. 2015, 195, 2580-2590. [CrossRef]

66. Stringaris, K.; Sekine, T.; Khoder, A.; Alsuliman, A.; Razzaghi, B.; Sargeant, R.; Pavlu, J.; Brisley, G.; de Lavallade, H.; Sarvaria, A.; et al. Leukemia-induced phenotypic and functional defects in natural killer cells predict failure to achieve remission in acute myeloid leukemia. Haematologica 2014, 99, 836-847. [CrossRef]

67. Sanchez-Correa, B.; Gayoso, I.; Bergua, J.M.; Casado, J.G.; Morgado, S.; Solana, R.; Tarazona, R. Decreased expression of DNAM-1 on NK cells from acute myeloid leukemia patients. Immunol. Cell Biol. 2012, 90, 109-115. [CrossRef]

68. Khaznadar, Z.; Henry, G.; Setterblad, N.; Agaugue, S.; Raffoux, E.; Boissel, N.; Dombret, H.; Toubert, A.; Dulphy, N. Acute myeloid leukemia impairs natural killer cells through the formation of a deficient cytotoxic immunological synapse. Eur. J. Immunol. 2014, 44, 3068-3080. [CrossRef]

69. Chan, C.J.; Martinet, L.; Gilfillan, S.; Souza-Fonseca-Guimaraes, F.; Chow, M.T.; Town, L.; Ritchie, D.S.; Colonna, M.; Andrews, D.M.; Smyth, M.J. The receptors CD96 and CD226 oppose each other in the regulation of natural killer cell functions. Nat. Immunol. 2014, 15, 431-438. [CrossRef]

70. Coles, S.J.; Wang, E.C.; Man, S.; Hills, R.K.; Burnett, A.K.; Tonks, A.; Darley, R.L. CD200 expression suppresses natural killer cell function and directly inhibits patient anti-tumor response in acute myeloid leukemia. Leukemia 2011, 25, 792-799. [CrossRef]

71. Hadadi, L.; Hafezi, M.; Amirzargar, A.A.; Sharifian, R.A.; Abediankenari, S.; Asgarian-Omran, H. Dysregulated Expression of Tim-3 and NKp30 Receptors on NK Cells of Patients with Chronic Lymphocytic Leukemia. Oncol. Res. Treat. 2019, 42, 202-208. [CrossRef]

72. Rabinovich, G.A.; Gabrilovich, D.; Sotomayor, E.M. Immunosuppressive strategies that are mediated by tumor cells. Annu. Rev. Immunol. 2007, 25, 267-296. [CrossRef]

73. Romero, A.I.; Thoren, F.B.; Brune, M.; Hellstrand, K. NKp46 and NKG2D receptor expression in NK cells with CD56dim and CD56bright phenotype: Regulation by histamine and reactive oxygen species. Br. J. Haematol. 2006, 132, 91-98. [CrossRef]

74. Szczepanski, M.J.; Szajnik, M.; Welsh, A.; Foon, K.A.; Whiteside, T.L.; Boyiadzis, M. Interleukin-15 enhances natural killer cell cytotoxicity in patients with acute myeloid leukemia by upregulating the activating NK cell receptors. Cancer Immunol. Immunother. 2010, 59, 73-79. [CrossRef]

75. Curti, A.; Trabanelli, S.; Salvestrini, V.; Baccarani, M.; Lemoli, R.M. The role of indoleamine 2,3-dioxygenase in the induction of immune tolerance: Focus on hematology. Blood 2009, 113, 2394-2401. [CrossRef] 
76. Della Chiesa, M.; Carlomagno, S.; Frumento, G.; Balsamo, M.; Cantoni, C.; Conte, R.; Moretta, L.; Moretta, A.; Vitale, M. The tryptophan catabolite L-kynurenine inhibits the surface expression of NKp46and NKG2D-activating receptors and regulates NK-cell function. Blood 2006, 108, 4118-4125. [CrossRef]

77. Hilpert, J.; Grosse-Hovest, L.; Grunebach, F.; Buechele, C.; Nuebling, T.; Raum, T.; Steinle, A.; Salih, H.R. Comprehensive analysis of NKG2D ligand expression and release in leukemia: Implications for NKG2D-mediated NK cell responses. J. Immunol. 2012, 189, 1360-1371. [CrossRef]

78. Clayton, A.; Mitchell, J.P.; Court, J.; Linnane, S.; Mason, M.D.; Tabi, Z. Human tumor-derived exosomes down-modulate NKG2D expression. J. Immunol. 2008, 180, 7249-7258. [CrossRef]

79. Reiners, K.S.; Topolar, D.; Henke, A.; Simhadri, V.R.; Kessler, J.; Sauer, M.; Bessler, M.; Hansen, H.P.; Tawadros, S.; Herling, M.; et al. Soluble ligands for NK cell receptors promote evasion of chronic lymphocytic leukemia cells from NK cell anti-tumor activity. Blood 2013, 121, 3658-3665. [CrossRef]

80. Chretien, A.S.; Fauriat, C.; Orlanducci, F.; Galseran, C.; Rey, J.; Bouvier Borg, G.; Gautherot, E.; Granjeaud, S.; Hamel-Broza, J.F.; Demerle, C.; et al. Natural Killer Defective Maturation Is Associated with Adverse Clinical Outcome in Patients with Acute Myeloid Leukemia. Front. Immunol. 2017, 8, 573. [CrossRef]

81. Schepers, K.; Campbell, T.B.; Passegue, E. Normal and leukemic stem cell niches: Insights and therapeutic opportunities. Cell Stem Cell 2015, 16, 254-267. [CrossRef]

82. Duan, C.W.; Shi, J.; Chen, J.; Wang, B.; Yu, Y.H.; Qin, X.; Zhou, X.C.; Cai, Y.J.; Li, Z.Q.; Zhang, F.; et al. Leukemia propagating cells rebuild an evolving niche in response to therapy. Cancer Cell 2014, 25, 778-793. [CrossRef]

83. Vasold, J.; Wagner, M.; Drolle, H.; Deniffel, C.; Kutt, A.; Oostendorp, R.; Sironi, S.; Rieger, C.; Fiegl, M. The bone marrow microenvironment is a critical player in the NK cell response against acute myeloid leukaemia in vitro. Leuk. Res. 2015, 39, 257-262. [CrossRef]

84. Vitale, C.; Ambrosini, P.; Montaldo, E.; Ballerini, F.; Moretta, L.; Mingari, M.C. IL-1beta-releasing human acute myeloid leukemia blasts modulate natural killer cell differentiation from CD34+ precursors. Haematologica 2015, 100, e42-e45. [CrossRef]

85. Ambrosini, P.; Loiacono, F.; Conte, R.; Moretta, L.; Vitale, C.; Mingari, M.C. IL-1beta inhibits ILC3 while favoring NK-cell maturation of umbilical cord blood CD34(+) precursors. Eur. J. Immunol. 2015, 45, 2061-2071. [CrossRef]

86. Scoville, S.D.; Nalin, A.P.; Chen, L.; Chen, L.; Zhang, M.H.; McConnell, K.; Beceiro Casas, S.; Ernst, G.; Traboulsi, A.A.; Hashi, N.; et al. Human AML activates the aryl hydrocarbon receptor pathway to impair NK cell development and function. Blood 2018, 132, 1792-1804. [CrossRef]

87. Bottcher, J.P.; Bonavita, E.; Chakravarty, P.; Blees, H.; Cabeza-Cabrerizo, M.; Sammicheli, S.; Rogers, N.C.; Sahai, E.; Zelenay, S.; Reis e Sousa, C. NK Cells Stimulate Recruitment of cDC1 into the Tumor Microenvironment Promoting Cancer Immune Control. Cell 2018, 172, 1022-1037.e14. [CrossRef]

88. Barry, K.C.; Hsu, J.; Broz, M.L.; Cueto, F.J.; Binnewies, M.; Combes, A.J.; Nelson, A.E.; Loo, K.; Kumar, R.; Rosenblum, M.D.; et al. A natural killer-dendritic cell axis defines checkpoint therapy-responsive tumor microenvironments. Nat. Med. 2018, 24, 1178-1191. [CrossRef]

89. Coca, S.; Perez-Piqueras, J.; Martinez, D.; Colmenarejo, A.; Saez, M.A.; Vallejo, C.; Martos, J.A.; Moreno, M. The prognostic significance of intratumoral natural killer cells in patients with colorectal carcinoma. Cancer 1997, 79, 2320-2328. [CrossRef]

90. Ishigami, S.; Natsugoe, S.; Tokuda, K.; Nakajo, A.; Che, X.; Iwashige, H.; Aridome, K.; Hokita, S.; Aikou, T. Prognostic value of intratumoral natural killer cells in gastric carcinoma. Cancer 2000, 88, 577-583. [CrossRef]

91. Villegas, F.R.; Coca, S.; Villarrubia, V.G.; Jimenez, R.; Chillon, M.J.; Jareno, J.; Zuil, M.; Callol, L. Prognostic significance of tumor infiltrating natural killer cells subset CD57 in patients with squamous cell lung cancer. Lung Cancer 2002, 35, 23-28. [CrossRef]

92. Schleypen, J.S.; Von Geldern, M.; Weiss, E.H.; Kotzias, N.; Rohrmann, K.; Schendel, D.J.; Falk, C.S.; Pohla, H. Renal cell carcinoma-infiltrating natural killer cells express differential repertoires of activating and inhibitory receptors and are inhibited by specific HLA class I allotypes. Int. J. Cancer 2003, 106, 905-912. [CrossRef]

93. Rusakiewicz, S.; Semeraro, M.; Sarabi, M.; Desbois, M.; Locher, C.; Mendez, R.; Vimond, N.; Concha, A.; Garrido, F.; Isambert, N.; et al. Immune infiltrates are prognostic factors in localized gastrointestinal stromal tumors. Cancer Res. 2013, 73, 3499-3510. [CrossRef] 
94. Mamessier, E.; Sylvain, A.; Bertucci, F.; Castellano, R.; Finetti, P.; Houvenaeghel, G.; Charaffe-Jaufret, E.; Birnbaum, D.; Moretta, A.; Olive, D. Human breast tumor cells induce self-tolerance mechanisms to avoid NKG2D-mediated and DNAM-mediated NK cell recognition. Cancer Res. 2011, 71, 6621-6632. [CrossRef]

95. Platonova, S.; Cherfils-Vicini, J.; Damotte, D.; Crozet, L.; Vieillard, V.; Validire, P.; Andre, P.; Dieu-Nosjean, M.C.; Alifano, M.; Regnard, J.F.; et al. Profound coordinated alterations of intratumoral NK cell phenotype and function in lung carcinoma. Cancer Res. 2011, 71, 5412-5422. [CrossRef]

96. Delahaye, N.F.; Rusakiewicz, S.; Martins, I.; Menard, C.; Roux, S.; Lyonnet, L.; Paul, P.; Sarabi, M.; Chaput, N.; Semeraro, M.; et al. Alternatively spliced NKp30 isoforms affect the prognosis of gastrointestinal stromal tumors. Nat. Med. 2011, 17, 700-707. [CrossRef]

97. Zhang, Q.; Bi, J.; Zheng, X.; Chen, Y.; Wang, H.; Wu, W.; Wang, Z.; Wu, Q.; Peng, H.; Wei, H.; et al. Blockade of the checkpoint receptor TIGIT prevents NK cell exhaustion and elicits potent anti-tumor immunity. Nat. Immunol. 2018, 19, 723-732. [CrossRef]

98. Zheng, Y.; Li, Y.; Lian, J.; Yang, H.; Li, F.; Zhao, S.; Qi, Y.; Zhang, Y.; Huang, L. TNF-alpha-induced Tim-3 expression marks the dysfunction of infiltrating natural killer cells in human esophageal cancer. J. Transl. Med. 2019, 17, 165. [CrossRef]

99. Wang, Z.; Zhu, J.; Gu, H.; Yuan, Y.; Zhang, B.; Zhu, D.; Zhou, J.; Zhu, Y.; Chen, W. The Clinical Significance of Abnormal Tim-3 Expression on NK Cells from Patients with Gastric Cancer. Immunol. Investig. 2015, 44, 578-589. [CrossRef]

100. Xu, L.; Huang, Y.; Tan, L.; Yu, W.; Chen, D.; Lu, C.; He, J.; Wu, G.; Liu, X.; Zhang, Y. Increased Tim-3 expression in peripheral NK cells predicts a poorer prognosis and Tim-3 blockade improves NK cell-mediated cytotoxicity in human lung adenocarcinoma. Int. Immunopharmacol. 2015, 29, 635-641. [CrossRef]

101. Da Silva, I.P.; Gallois, A.; Jimenez-Baranda, S.; Khan, S.; Anderson, A.C.; Kuchroo, V.K.; Osman, I.; Bhardwaj, N. Reversal of NK-cell exhaustion in advanced melanoma by Tim-3 blockade. Cancer Immunol. Res. 2014, 2, 410-422. [CrossRef]

102. Sun, H.; Liu, L.; Huang, Q.; Liu, H.; Huang, M.; Wang, J.; Wen, H.; Lin, R.; Qu, K.; Li, K.; et al. Accumulation of Tumor-Infiltrating CD49a(+) NK Cells Correlates with Poor Prognosis for Human Hepatocellular Carcinoma. Cancer Immunol. Res. 2019, 7, 1535-1546. [CrossRef] [PubMed]

103. Beldi-Ferchiou, A.; Lambert, M.; Dogniaux, S.; Vely, F.; Vivier, E.; Olive, D.; Dupuy, S.; Levasseur, F.; Zucman, D.; Lebbe, C.; et al. PD-1 mediates functional exhaustion of activated NK cells in patients with Kaposi sarcoma. Oncotarget 2016, 7, 72961-72977. [CrossRef] [PubMed]

104. Tabellini, G.; Benassi, M.; Marcenaro, E.; Coltrini, D.; Patrizi, O.; Ricotta, D.; Rampinelli, F.; Moretta, A.; Parolini, S. Primitive neuroectodermal tumor in an ovarian cystic teratoma: Natural killer and neuroblastoma cell analysis. Case Rep. Oncol. 2014, 7, 70-78. [CrossRef]

105. Anderson, A.C.; Joller, N.; Kuchroo, V.K. Lag-3, Tim-3, and TIGIT: Co-inhibitory Receptors with Specialized Functions in Immune Regulation. Immunity 2016, 44, 989-1004. [CrossRef]

106. De Andrade, L.F.; Lu, Y.; Luoma, A.; Ito, Y.; Pan, D.; Pyrdol, J.W.; Yoon, C.H.; Yuan, G.C.; Wucherpfennig, K.W. Discovery of specialized NK cell populations infiltrating human melanoma metastases. JCI Insight 2019, 4. [CrossRef]

107. Gabrilovich, D.I.; Ostrand-Rosenberg, S.; Bronte, V. Coordinated regulation of myeloid cells by tumours. Nat. Rev. Immunol. 2012, 12, 253-268. [CrossRef]

108. Ghiringhelli, F.; Menard, C.; Terme, M.; Flament, C.; Taieb, J.; Chaput, N.; Puig, P.E.; Novault, S.; Escudier, B.; Vivier, E.; et al. CD4+CD25+ regulatory T cells inhibit natural killer cell functions in a transforming growth factor-beta-dependent manner. J. Exp. Med. 2005, 202, 1075-1085. [CrossRef]

109. Li, T.; Yang, Y.; Hua, X.; Wang, G.; Liu, W.; Jia, C.; Tai, Y.; Zhang, Q.; Chen, G. Hepatocellular carcinoma-associated fibroblasts trigger NK cell dysfunction via PGE2 and IDO. Cancer Lett. 2012, 318, 154-161. [CrossRef]

110. Li, T.; Yi, S.; Liu, W.; Jia, C.; Wang, G.; Hua, X.; Tai, Y.; Zhang, Q.; Chen, G. Colorectal carcinoma-derived fibroblasts modulate natural killer cell phenotype and antitumor cytotoxicity. Med. Oncol. 2013, 30, 663. [CrossRef]

111. Balsamo, M.; Scordamaglia, F.; Pietra, G.; Manzini, C.; Cantoni, C.; Boitano, M.; Queirolo, P.; Vermi, W.; Facchetti, F.; Moretta, A.; et al. Melanoma-associated fibroblasts modulate NK cell phenotype and antitumor cytotoxicity. Proc. Natl. Acad. Sci. USA 2009, 106, 20847-20852. [CrossRef] 
112. Pietra, G.; Manzini, C.; Rivara, S.; Vitale, M.; Cantoni, C.; Petretto, A.; Balsamo, M.; Conte, R.; Benelli, R.; Minghelli, S.; et al. Melanoma cells inhibit natural killer cell function by modulating the expression of activating receptors and cytolytic activity. Cancer Res. 2012, 72, 1407-1415. [CrossRef]

113. Hoskin, D.W.; Mader, J.S.; Furlong, S.J.; Conrad, D.M.; Blay, J. Inhibition of T cell and natural killer cell function by adenosine and its contribution to immune evasion by tumor cells (Review). Int. J. Oncol. 2008, 32, 527-535. [CrossRef]

114. Bottino, C.; Dondero, A.; Bellora, F.; Moretta, L.; Locatelli, F.; Pistoia, V.; Moretta, A.; Castriconi, R. Natural killer cells and neuroblastoma: Tumor recognition, escape mechanisms, and possible novel immunotherapeutic approaches. Front. Immunol. 2014, 5, 56. [CrossRef]

115. Krockenberger, M.; Dombrowski, Y.; Weidler, C.; Ossadnik, M.; Honig, A.; Hausler, S.; Voigt, H.; Becker, J.C.; Leng, L.; Steinle, A.; et al. Macrophage migration inhibitory factor contributes to the immune escape of ovarian cancer by down-regulating NKG2D. J. Immunol. 2008, 180, 7338-7348. [CrossRef]

116. Gubbels, J.A.; Felder, M.; Horibata, S.; Belisle, J.A.; Kapur, A.; Holden, H.; Petrie, S.; Migneault, M.; Rancourt, C.; Connor, J.P.; et al. MUC16 provides immune protection by inhibiting synapse formation between NK and ovarian tumor cells. Mol. Cancer 2010, 9, 11. [CrossRef]

117. Groh, V.; Wu, J.; Yee, C.; Spies, T. Tumour-derived soluble MIC ligands impair expression of NKG2D and T-cell activation. Nature 2002, 419, 734-738. [CrossRef]

118. Kaiser, B.K.; Yim, D.; Chow, I.T.; Gonzalez, S.; Dai, Z.; Mann, H.H.; Strong, R.K.; Groh, V.; Spies, T. Disulphide-isomerase-enabled shedding of tumour-associated NKG2D ligands. Nature 2007, 447, 482-486. [CrossRef]

119. Rosental, B.; Brusilovsky, M.; Hadad, U.; Oz, D.; Appel, M.Y.; Afergan, F.; Yossef, R.; Rosenberg, L.A.; Aharoni, A.; Cerwenka, A.; et al. Proliferating cell nuclear antigen is a novel inhibitory ligand for the natural cytotoxicity receptor NKp44. J. Immunol. 2011, 187, 5693-5702. [CrossRef]

120. Balsamo, M.; Manzini, C.; Pietra, G.; Raggi, F.; Blengio, F.; Mingari, M.C.; Varesio, L.; Moretta, L.; Bosco, M.C.; Vitale, M. Hypoxia downregulates the expression of activating receptors involved in NK-cell-mediated target cell killing without affecting ADCC. Eur. J. Immunol. 2013, 43, 2756-2764. [CrossRef]

121. Saglio, G.; Jabbour, E. First-line therapy for chronic phase CML: Selecting the optimal BCR-ABL1-targeted TKI. Leuk. Lymphoma 2018, 59, 1523-1538. [CrossRef]

122. El Fakih, R.; Jabbour, E.; Ravandi, F.; Hassanein, M.; Anjum, F.; Ahmed, S.; Kantarjian, H. Current paradigms in the management of Philadelphia chromosome positive acute lymphoblastic leukemia in adults. Am. J. Hematol. 2018, 93, 286-295. [CrossRef] [PubMed]

123. Kiyoi, H. Flt3 Inhibitors: Recent Advances and Problems for Clinical Application. Nagoya J. Med. Sci. 2015, 77, 7-17. [PubMed]

124. Fernandez, S.; Desplat, V.; Villacreces, A.; Guitart, A.V.; Milpied, N.; Pigneux, A.; Vigon, I.; Pasquet, J.M.; Dumas, P.Y. Targeting Tyrosine Kinases in Acute Myeloid Leukemia: Why, Who and How? Int. J. Mol. Sci. 2019, 20, 3429. [CrossRef] [PubMed]

125. Tefferi, A. Myelofibrosis with myeloid metaplasia. N. Engl. J. Med. 2000, 342, 1255-1265. [CrossRef]

126. Percy, M.J.; McMullin, M.F. The V617F JAK2 mutation and the myeloproliferative disorders. Hematol. Oncol. 2005, 23, 91-93. [CrossRef]

127. Heinrich, M.C.; Corless, C.L.; Demetri, G.D.; Blanke, C.D.; von Mehren, M.; Joensuu, H.; McGreevey, L.S.; Chen, C.J.; Van den Abbeele, A.D.; Druker, B.J.; et al. Kinase mutations and imatinib response in patients with metastatic gastrointestinal stromal tumor. J. Clin. Oncol. Off. J. Am. Soc. Clin. Oncol. 2003, 21, 4342-4349. [CrossRef]

128. Hemming, M.L.; Heinrich, M.C.; Bauer, S.; George, S. Translational insights into gastrointestinal stromal tumor and current clinical advances. Ann. Oncol. 2018, 29, 2037-2045. [CrossRef]

129. Vuky, J.; Isacson, C.; Fotoohi, M.; dela Cruz, J.; Otero, H.; Picozzi, V.; Malpass, T.; Aboulafia, D.; Jacobs, A. Phase II trial of imatinib (Gleevec) in patients with metastatic renal cell carcinoma. Investig. New Drugs 2006, 24, 85-88. [CrossRef]

130. Bauman, J.E.; Eaton, K.D.; Martins, R.G. Antagonism of platelet-derived growth factor receptor in non small cell lung cancer: Rationale and investigations. Clin. Cancer Res. An Off. J. Am. Assoc. Cancer Res. 2007, 13, s4632-s4636. [CrossRef]

131. Pane, F.; Intrieri, M.; Quintarelli, C.; Izzo, B.; Muccioli, G.C.; Salvatore, F. BCR/ABL genes and leukemic phenotype: From molecular mechanisms to clinical correlations. Oncogene 2002, 21, 8652-8667. [CrossRef] 
132. Eide, C.A.; O'Hare, T. Chronic myeloid leukemia: Advances in understanding disease biology and mechanisms of resistance to tyrosine kinase inhibitors. Curr. Hematol. Malig. Rep. 2015, 10, 158-166. [CrossRef]

133. Byrd, J.C.; Brown, J.R.; O’Brien, S.; Barrientos, J.C.; Kay, N.E.; Reddy, N.M.; Coutre, S.; Tam, C.S.; Mulligan, S.P.; Jaeger, U.; et al. Ibrutinib versus ofatumumab in previously treated chronic lymphoid leukemia. N. Engl. J. Med. 2014, 371, 213-223. [CrossRef] [PubMed]

134. Roberts, A.W.; Davids, M.S.; Pagel, J.M.; Kahl, B.S.; Puvvada, S.D.; Gerecitano, J.F.; Kipps, T.J.; Anderson, M.A.; Brown, J.R.; Gressick, L.; et al. Targeting BCL2 with Venetoclax in Relapsed Chronic Lymphocytic Leukemia. N. Engl. J. Med. 2016, 374, 311-322. [CrossRef]

135. Woyach, J.A.; Furman, R.R.; Liu, T.M.; Ozer, H.G.; Zapatka, M.; Ruppert, A.S.; Xue, L.; Li, D.H.; Steggerda, S.M.; Versele, M.; et al. Resistance mechanisms for the Bruton's tyrosine kinase inhibitor ibrutinib. N. Engl. J. Med. 2014, 370, 2286-2294. [CrossRef] [PubMed]

136. Herling, C.D.; Abedpour, N.; Weiss, J.; Schmitt, A.; Jachimowicz, R.D.; Merkel, O.; Cartolano, M.; Oberbeck, S.; Mayer, P.; Berg, V.; et al. Clonal dynamics towards the development of venetoclax resistance in chronic lymphocytic leukemia. Nat. Commun. 2018, 9, 727. [CrossRef] [PubMed]

137. Krieg, S.; Ullrich, E. Novel immune modulators used in hematology: Impact on NK cells. Front. Immunol. 2012, 3, 388. [CrossRef] [PubMed]

138. Carlsten, M.; Jaras, M. Natural Killer Cells in Myeloid Malignancies: Immune Surveillance, NK Cell Dysfunction, and Pharmacological Opportunities to Bolster the Endogenous NK Cells. Front. Immunol. 2019, 10, 2357. [CrossRef]

139. Zitvogel, L.; Rusakiewicz, S.; Routy, B.; Ayyoub, M.; Kroemer, G. Immunological off-target effects of imatinib. Nat. Rev. Clin. Oncol. 2016, 13, 431-446. [CrossRef]

140. McLornan, D.P.; Khan, A.A.; Harrison, C.N. Immunological Consequences of JAK Inhibition: Friend or Foe? Curr. Hematol. Malig. Rep. 2015, 10, 370-379. [CrossRef]

141. Schonberg, K.; Rudolph, J.; Vonnahme, M.; Parampalli Yajnanarayana, S.; Cornez, I.; Hejazi, M.; Manser, A.R.; Uhrberg, M.; Verbeek, W.; Koschmieder, S.; et al. JAK Inhibition Impairs NK Cell Function in Myeloproliferative Neoplasms. Cancer Res. 2015, 75, 2187-2199. [CrossRef]

142. Kohrt, H.E.; Sagiv-Barfi, I.; Rafiq, S.; Herman, S.E.; Butchar, J.P.; Cheney, C.; Zhang, X.; Buggy, J.J.; Muthusamy, N.; Levy, R.; et al. Ibrutinib antagonizes rituximab-dependent NK cell-mediated cytotoxicity. Blood 2014, 123, 1957-1960. [CrossRef] [PubMed]

143. Salih, J.; Hilpert, J.; Placke, T.; Grunebach, F.; Steinle, A.; Salih, H.R.; Krusch, M. The BCR/ABL-inhibitors imatinib, nilotinib and dasatinib differentially affect NK cell reactivity. Int. J. Cancer 2010, 127, 2119-2128. [CrossRef] [PubMed]

144. Houshmand, M.; Blanco, T.M.; Circosta, P.; Yazdi, N.; Kazemi, A.; Saglio, G.; Zarif, M.N. Bone marrow microenvironment: The guardian of leukemia stem cells. World J. Stem Cells 2019, 11, 476-490. [CrossRef] [PubMed]

145. Appel, S.; Balabanov, S.; Brummendorf, T.H.; Brossart, P. Effects of imatinib on normal hematopoiesis and immune activation. Stem Cells 2005, 23, 1082-1088. [CrossRef] [PubMed]

146. Damele, L.; Montaldo, E.; Moretta, L.; Vitale, C.; Mingari, M.C. Effect of Tyrosin Kinase Inhibitors on NK Cell and ILC3 Development and Function. Front. Immunol. 2018, 9, 2433. [CrossRef] [PubMed]

147. Christiansson, L.; Soderlund, S.; Mangsbo, S.; Hjorth-Hansen, H.; Hoglund, M.; Markevarn, B.; Richter, J.; Stenke, L.; Mustjoki, S.; Loskog, A.; et al. The tyrosine kinase inhibitors imatinib and dasatinib reduce myeloid suppressor cells and release effector lymphocyte responses. Mol. Cancer Ther. 2015, 14, 1181-1191. [CrossRef] [PubMed]

148. Tanaka, A.; Nishikawa, H.; Noguchi, S.; Sugiyama, D.; Morikawa, H.; Takeuchi, Y.; Ha, D.; Shigeta, N.; Kitawaki, T.; Maeda, Y.; et al. Tyrosine kinase inhibitor imatinib augments tumor immunity by depleting effector regulatory T cells. J. Exp. Med. 2020, 217. [CrossRef]

149. Hayashi, Y.; Nakamae, H.; Katayama, T.; Nakane, T.; Koh, H.; Nakamae, M.; Hirose, A.; Hagihara, K.; Terada, Y.; Nakao, Y.; et al. Different immunoprofiles in patients with chronic myeloid leukemia treated with imatinib, nilotinib or dasatinib. Leuk. Lymphoma 2012, 53, 1084-1089. [CrossRef]

150. Mustjoki, S.; Auvinen, K.; Kreutzman, A.; Rousselot, P.; Hernesniemi, S.; Melo, T.; Lahesmaa-Korpinen, A.M.; Hautaniemi, S.; Bouchet, S.; Molimard, M.; et al. Rapid mobilization of cytotoxic lymphocytes induced by dasatinib therapy. Leukemia 2013, 27, 914-924. [CrossRef] 
151. El Missiry, M.; Adnan Awad, S.; Rajala, H.L.; Al-Samadi, A.; Ekblom, M.; Markevan, B.; Astrand-Grundstrom, I.; Wold, M.; Svedahl, E.R.; Juhl, B.R.; et al. Assessment of bone marrow lymphocytic status during tyrosine kinase inhibitor therapy and its relation to therapy response in chronic myeloid leukaemia. J. Cancer Res. Clin. Oncol. 2016, 142, 1041-1050. [CrossRef]

152. Binotto, G.; Frison, L.; Boscaro, E.; Zambello, R.; Lessi, F.; Parolo, A.; Piazza, F.; Bertorelle, R.; Bonaldi, L.; Semenzato, G. Comparative Analysis of NK Receptor and T-Cell Receptor Repertoires in Patients with Chronic Myeloid Leukemia Treated with Different Tyrosine Kinase Inhibitors. Blood 2014, 124, 5508. [CrossRef]

153. Chang, M.C.; Cheng, H.I.; Hsu, K.; Hsu, Y.N.; Kao, C.W.; Chang, Y.F.; Lim, K.H.; Chen, C.G. NKG2A Down-Regulation by Dasatinib Enhances Natural Killer Cytotoxicity and Accelerates Effective Treatment Responses in Patients With Chronic Myeloid Leukemia. Front. Immunol. 2018, 9, 3152. [CrossRef] [PubMed]

154. Hughes, A.; Clarson, J.; Tang, C.; Vidovic, L.; White, D.L.; Hughes, T.P.; Yong, A.S. CML patients with deep molecular responses to TKI have restored immune effectors and decreased PD-1 and immune suppressors. Blood 2017, 129, 1166-1176. [CrossRef] [PubMed]

155. Cortes, J.; Rea, D.; Lipton, J.H. Treatment-free remission with first- and second-generation tyrosine kinase inhibitors. Am. J. Hematol. 2019, 94, 346-357. [CrossRef]

156. Shanmuganathan, N.; Hughes, T.P. Molecular monitoring in CML: How deep? How often? How should it influence therapy? Blood 2018, 132, 2125-2133. [CrossRef]

157. Hughes, A.; Yong, A.S.M. Immune Effector Recovery in Chronic Myeloid Leukemia and Treatment-Free Remission. Front. Immunol. 2017, 8, 469. [CrossRef]

158. Clapp, G.D.; Lepoutre, T.; Nicolini, F.E.; Levy, D. BCR-ABL transcript variations in chronic phase chronic myelogenous leukemia patients on imatinib first-line: Possible role of the autologous immune system. Oncoimmunology 2016, 5, e1122159. [CrossRef]

159. Ilander, M.; Olsson-Stromberg, U.; Schlums, H.; Guilhot, J.; Bruck, O.; Lahteenmaki, H.; Kasanen, T.; Koskenvesa, P.; Soderlund, S.; Hoglund, M.; et al. Increased proportion of mature NK cells is associated with successful imatinib discontinuation in chronic myeloid leukemia. Leukemia 2017, 31, 1108-1116. [CrossRef]

160. Imagawa, J.; Tanaka, H.; Okada, M.; Nakamae, H.; Hino, M.; Murai, K.; Ishida, Y.; Kumagai, T.; Sato, S.; Ohashi, K.; et al. Discontinuation of dasatinib in patients with chronic myeloid leukaemia who have maintained deep molecular response for longer than 1 year (DADI trial): A multicentre phase 2 trial. Lancet Haematol. 2015, 2, e528-e535. [CrossRef]

161. Rea, D.; Henry, G.; Khaznadar, Z.; Etienne, G.; Guilhot, F.; Nicolini, F.; Guilhot, J.; Rousselot, P.; Huguet, F.; Legros, L.; et al. Natural killer-cell counts are associated with molecular relapse-free survival after imatinib discontinuation in chronic myeloid leukemia: The IMMUNOSTIM study. Haematologica 2017, 102, 1368-1377. [CrossRef]

162. Kumagai, T.; Nakaseko, C.; Nishiwaki, K.; Yoshida, C.; Ohashi, K.; Takezako, N.; Takano, H.; Kouzai, Y.; Murase, T.; Matsue, K.; et al. Dasatinib cessation after deep molecular response exceeding 2 years and natural killer cell transition during dasatinib consolidation. Cancer Sci. 2018, 109, 182-192. [CrossRef] [PubMed]

163. Ureshino, H.; Shindo, T.; Kojima, H.; Kusunoki, Y.; Miyazaki, Y.; Tanaka, H.; Saji, H.; Kawaguchi, A.; Kimura, S. Allelic Polymorphisms of KIRs and HLAs Predict Favorable Responses to Tyrosine Kinase Inhibitors in CML. Cancer Immunol. Res. 2018, 6, 745-754. [CrossRef] [PubMed]

164. Marin, D.; Gabriel, I.H.; Ahmad, S.; Foroni, L.; de Lavallade, H.; Clark, R.; O’Brien, S.; Sergeant, R.; Hedgley, C.; Milojkovic, D.; et al. KIR2DS1 genotype predicts for complete cytogenetic response and survival in newly diagnosed chronic myeloid leukemia patients treated with imatinib. Leukemia 2012, 26, 296-302. [CrossRef] [PubMed]

165. Yeung, D.T.; Tang, C.; Vidovic, L.; White, D.L.; Branford, S.; Hughes, T.P.; Yong, A.S. KIR2DL5B genotype predicts outcomes in CML patients treated with response-directed sequential imatinib/nilotinib strategy. Blood 2015, 126, 2720-2723. [CrossRef] [PubMed]

166. Menard, C.; Blay, J.Y.; Borg, C.; Michiels, S.; Ghiringhelli, F.; Robert, C.; Nonn, C.; Chaput, N.; Taieb, J.; Delahaye, N.F.; et al. Natural killer cell IFN-gamma levels predict long-term survival with imatinib mesylate therapy in gastrointestinal stromal tumor-bearing patients. Cancer Res. 2009, 69, 3563-3569. [CrossRef] [PubMed] 
167. Rusakiewicz, S.; Perier, A.; Semeraro, M.; Pitt, J.M.; Pogge von Strandmann, E.; Reiners, K.S.; Aspeslagh, S.; Piperoglou, C.; Vely, F.; Ivagnes, A.; et al. NKp30 isoforms and NKp30 ligands are predictive biomarkers of response to imatinib mesylate in metastatic GIST patients. Oncoimmunology 2017, 6, e1137418. [CrossRef] [PubMed]

168. Davies, H.; Bignell, G.R.; Cox, C.; Stephens, P.; Edkins, S.; Clegg, S.; Teague, J.; Woffendin, H.; Garnett, M.J.; Bottomley, W.; et al. Mutations of the BRAF gene in human cancer. Nature 2002, 417, 949-954. [CrossRef]

169. Tiacci, E.; Trifonov, V.; Schiavoni, G.; Holmes, A.; Kern, W.; Martelli, M.P.; Pucciarini, A.; Bigerna, B.; Pacini, R.; Wells, V.A.; et al. BRAF mutations in hairy-cell leukemia. N. Engl. J. Med. 2011, 364, 2305-2315. [CrossRef]

170. Xing, M. BRAF mutation in thyroid cancer. Endocr. Relat. Cancer 2005, 12, 245-262. [CrossRef]

171. Maurer, G.; Tarkowski, B.; Baccarini, M. Raf kinases in cancer-roles and therapeutic opportunities. Oncogene 2011, 30, 3477-3488. [CrossRef]

172. Flaherty, K.T.; Puzanov, I.; Kim, K.B.; Ribas, A.; McArthur, G.A.; Sosman, J.A.; O’Dwyer, P.J.; Lee, R.J.; Grippo, J.F.; Nolop, K.; et al. Inhibition of mutated, activated BRAF in metastatic melanoma. N. Engl. J. Med. 2010, 363, 809-819. [CrossRef] [PubMed]

173. Chapman, P.B.; Hauschild, A.; Robert, C.; Haanen, J.B.; Ascierto, P.; Larkin, J.; Dummer, R.; Garbe, C.; Testori, A.; Maio, M.; et al. Improved survival with vemurafenib in melanoma with BRAF V600E mutation. N. Engl. J. Med. 2011, 364, 2507-2516. [CrossRef] [PubMed]

174. Flaherty, K.T.; Smalley, K.S. Preclinical and clinical development of targeted therapy in melanoma: Attention to schedule. Pigment. Cell Melanoma Res. 2009, 22, 529-531. [CrossRef] [PubMed]

175. Spagnolo, F.; Ghiorzo, P.; Queirolo, P. Overcoming resistance to BRAF inhibition in BRAF-mutated metastatic melanoma. Oncotarget 2014, 5, 10206-10221. [CrossRef] [PubMed]

176. Flaherty, K.T.; Infante, J.R.; Daud, A.; Gonzalez, R.; Kefford, R.F.; Sosman, J.; Hamid, O.; Schuchter, L.; Cebon, J.; Ibrahim, N.; et al. Combined BRAF and MEK inhibition in melanoma with BRAF V600 mutations. N. Engl. J. Med. 2012, 367, 1694-1703. [CrossRef]

177. Larkin, J.; Ascierto, P.A.; Dreno, B.; Atkinson, V.; Liszkay, G.; Maio, M.; Mandala, M.; Demidov, L.; Stroyakovskiy, D.; Thomas, L.; et al. Combined vemurafenib and cobimetinib in BRAF-mutated melanoma. N. Engl. J. Med. 2014, 371, 1867-1876. [CrossRef]

178. Sumimoto, H.; Imabayashi, F.; Iwata, T.; Kawakami, Y. The BRAF-MAPK signaling pathway is essential for cancer-immune evasion in human melanoma cells. J. Exp. Med. 2006, 203, 1651-1656. [CrossRef]

179. Knight, D.A.; Ngiow, S.F.; Li, M.; Parmenter, T.; Mok, S.; Cass, A.; Haynes, N.M.; Kinross, K.; Yagita, H.; Koya, R.C.; et al. Host immunity contributes to the anti-melanoma activity of BRAF inhibitors. J. Clin. Investig. 2013, 123, 1371-1381. [CrossRef]

180. Ferrari de Andrade, L.; Ngiow, S.F.; Stannard, K.; Rusakiewicz, S.; Kalimutho, M.; Khanna, K.K.; Tey, S.K.; Takeda, K.; Zitvogel, L.; Martinet, L.; et al. Natural killer cells are essential for the ability of BRAF inhibitors to control BRAFV600E-mutant metastatic melanoma. Cancer Res. 2014, 74, 7298-7308. [CrossRef]

181. Manzini, C.; Vene, R.; Cossu, I.; Gualco, M.; Zupo, S.; Dono, M.; Spagnolo, F.; Queirolo, P.; Moretta, L.; Mingari, M.C.; et al. Cytokines can counteract the inhibitory effect of MEK-i on NK-cell function. Oncotarget 2016, 7, 60858-60871. [CrossRef]

182. Schilling, B.; Sondermann, W.; Zhao, F.; Griewank, K.G.; Livingstone, E.; Sucker, A.; Zelba, H.; Weide, B.; Trefzer, U.; Wilhelm, T.; et al. Differential influence of vemurafenib and dabrafenib on patients' lymphocytes despite similar clinical efficacy in melanoma. Ann. Oncol. 2014, 25, 747-753. [CrossRef] [PubMed]

183. Li, C.; Wei, S.; Xu, X.; Jiang, Y.; Xue, L.; Jiang, P.; Wang, J. Sorafenib attenuated the function of natural killer cells infiltrated in HCC through inhibiting ERK1/2. Int. Immunopharmacol. 2019, 76, 105855. [CrossRef] [PubMed]

184. Bottos, A.; Gotthardt, D.; Gill, J.W.; Gattelli, A.; Frei, A.; Tzankov, A.; Sexl, V.; Wodnar-Filipowicz, A.; Hynes, N.E. Decreased NK-cell tumour immunosurveillance consequent to JAK inhibition enhances metastasis in breast cancer models. Nat. Commun. 2016, 7, 12258. [CrossRef] [PubMed]

185. Lopez-Cobo, S.; Pieper, N.; Campos-Silva, C.; Garcia-Cuesta, E.M.; Reyburn, H.T.; Paschen, A.; Vales-Gomez, M. Impaired NK cell recognition of vemurafenib-treated melanoma cells is overcome by simultaneous application of histone deacetylase inhibitors. Oncoimmunology 2018, 7, e1392426. [CrossRef]

186. Furfaro, A.L.; Ottonello, S.; Loi, G.; Cossu, I.; Piras, S.; Spagnolo, F.; Queirolo, P.; Marinari, U.M.; Moretta, L.; Pronzato, M.A.; et al. HO-1 downregulation favors BRAF(V600) melanoma cell death induced by Vemurafenib/PLX4032 and increases NK recognition. Int. J. Cancer 2020, 146, 1950-1962. [CrossRef] 
187. Dominguez, C.; Tsang, K.Y.; Palena, C. Short-term EGFR blockade enhances immune-mediated cytotoxicity of EGFR mutant lung cancer cells: Rationale for combination therapies. Cell Death Dis. 2016, 7, e2380. [CrossRef]

188. Robert, L.; Ribas, A.; Hu-Lieskovan, S. Combining targeted therapy with immunotherapy. Can $1+1$ equal more than 2? Semin. Immunol. 2016, 28, 73-80. [CrossRef]

189. Hughes, P.E.; Caenepeel, S.; Wu, L.C. Targeted Therapy and Checkpoint Immunotherapy Combinations for the Treatment of Cancer. Trends Immunol. 2016, 37, 462-476. [CrossRef]

190. Vitale, M.; Della Chiesa, M.; Carlomagno, S.; Pende, D.; Arico, M.; Moretta, L.; Moretta, A. NK-dependent DC maturation is mediated by TNFalpha and IFNgamma released upon engagement of the NKp30 triggering receptor. Blood 2005, 106, 566-571. [CrossRef]

191. Marcenaro, E.; Carlomagno, S.; Pesce, S.; Moretta, A.; Sivori, S. Bridging innate NK cell functions with adaptive immunity. Adv. Exp. Med. Biol. 2011, 780, 45-55. [CrossRef]

192. Karachaliou, N.; Gonzalez-Cao, M.; Sosa, A.; Berenguer, J.; Bracht, J.W.P.; Ito, M.; Rosell, R. The combination of checkpoint immunotherapy and targeted therapy in cancer. Ann. Transl. Med. 2017, 5, 388. [CrossRef] [PubMed]

193. Sanchez-Correa, B.; Lopez-Sejas, N.; Duran, E.; Labella, F.; Alonso, C.; Solana, R.; Tarazona, R. Modulation of NK cells with checkpoint inhibitors in the context of cancer immunotherapy. Cancer Immunol. Immunother. 2019, 68, 861-870. [CrossRef] [PubMed]

(C) 2020 by the authors. Licensee MDPI, Basel, Switzerland. This article is an open access article distributed under the terms and conditions of the Creative Commons Attribution (CC BY) license (http://creativecommons.org/licenses/by/4.0/). 